\title{
"Heroes" and "Whores": The Politics of Gender in Weimar Antiwar Imagery
}

\section{Dora Apel}

The Art Bulletin, Vol. 79, No. 3. (Sep., 1997), pp. 366-384.

Stable URL:

http://links.jstor.org/sici?sici=0004-3079\%28199709\%2979\%3A3\%3C366\%3A\%22A\%22TPO\%3E2.0.CO\%3B2-S

The Art Bulletin is currently published by College Art Association.

Your use of the JSTOR archive indicates your acceptance of JSTOR's Terms and Conditions of Use, available at http://www.jstor.org/about/terms.html. JSTOR's Terms and Conditions of Use provides, in part, that unless you have obtained prior permission, you may not download an entire issue of a journal or multiple copies of articles, and you may use content in the JSTOR archive only for your personal, non-commercial use.

Please contact the publisher regarding any further use of this work. Publisher contact information may be obtained at http://www.jstor.org/journals/caa.html.

Each copy of any part of a JSTOR transmission must contain the same copyright notice that appears on the screen or printed page of such transmission.

The JSTOR Archive is a trusted digital repository providing for long-term preservation and access to leading academic journals and scholarly literature from around the world. The Archive is supported by libraries, scholarly societies, publishers, and foundations. It is an initiative of JSTOR, a not-for-profit organization with a mission to help the scholarly community take advantage of advances in technology. For more information regarding JSTOR, please contact support@ jstor.org. 


\title{
"Heroes" and "Whores": The Politics of Gender in Weimar Antiwar Imagery
}

\author{
Dora Apel
}

At the peak of a debate over the memory and meaning of World War I, the ten-year anniversary of war mobilization in 1924 became the crucial point of convergence for many of the social and political issues that had surfaced in antiwar imagery in Germany. During this moment of intensified concentration on themes of war, antiwar imagery was presented in art exhibitions, left-wing periodicals, mass-produced lithographic portfolios, and photographic albums. Antiwar pictures were exhibited in the anarcho-pacifist Ernst Friedrich's newly founded International Antiwar Museum in Berlin and distributed through the cultural arm of the GermanSoviet International Workers' Aid. War photographs previously censored by the German government during the war, along with prints from Otto Dix's fifty-part etching series Der Krieg (War), produced in 1924, and Käthe Kollwitz's 1923 suite of seven woodcuts entitled Krieg (War), were exhibited together in Friedrich's Antiwar Museum in August 1924, thereby publicly linking the two preeminent antiwar artists in Germany, Dix and Kollwitz, with the pacifist propagandist Ernst Friedrich at the height of commemorative activities.

At the same time, Friedrich published the first book of war photographs to appear in postwar Germany. While his photographic narrative produced a different effect from that of the art of Kollwitz or Dix, all were part of the visual field representing the pacifist discourse. Friedrich saw war photography as the most expedient medium in which to put forward his own brand of pacifist political argument. Kollwitz, whose most famous antiwar images were commissioned by Social Democratic organizations, put her images to political use representing Social Democratic pacifism. Dix, distrusting straightforward political rhetoric, was more ironic and intentionally ambiguous in his imagery, assuming the stance of the independent, avant-garde artist. Nonetheless his works were widely regarded as pacifist interventions and became highly controversial. The examination of conflicting ideological positions among Weimar artists makes it possible to relate both the production and volatile reception of antiwar imagery by Dix, Friedrich, and Kollwitz to the Weimar debate over World War I and its implications for the construction of

I wish to thank Joan Weinstein, Sabine Hake, Barbara McCloskey, Gregory Wittkopp, and Isabela Basombrio for their insightful readings of earlier drafts of this article, as well as Nancy Troy, Paul Jaskot, and the anonymous Art Bulletin reader for their perceptive comments and suggestions. Translations are mine unless otherwise noted. All reproduced works by Otto Dix are $\odot 1996$ Artists Rights Society (ARS), New York/VG Bild-Kunst, Bonn.

1. For a recent exception, see Maria Tatar, Lustmord: Sexual Murder in Wermar Germany, Princeton, 1995, esp. 3-19, on Otto Dix. Tatar provides a psychoanalytic reading of Dix's wartime imagery in which she posits the ahistorical idea that men, unable to have babies, compete with women's procreative powers by making war. More provocatively, she suggests that the feminine gendering of violent death and mutilation in the postwar Lustmord (rape murder) pictures represents a displacement of physical trauma to the male body during the war. However, Tatar leaves aside the possible political implications of this imagery and again interprets it as the artists' misogynist jealousy of women evoked by their procreative powers. For more politically oriented discussions of Lustmord, masculine or feminine subjectivity in visual representations of soldiers and veterans or in images of rape, prostitution, and proletarian women.

Such presentations of gendered subjectivity in Weimar art have been left largely unexamined in the art historical literature. ${ }^{1}$ Yet a look at antiwar imagery raises a number of provocative questions about the representation of soldiers and women. German soldiers were often depicted as morally and physically "pure," while female prostitutes were portrayed as corrupters of soldier-males and of the nation. Idealized presentations of proletarian women played on stereotypes of the mother as a self-sacrificing icon who inevitably, if tragically, dedicated herself to motherhood, forsaking both a sensual and political life. Did women, assumed to be naturally pacifistic because of their maternal nature, bear a greater responsibility for the war by failing to oppose the mobilization of their husbands, sons, and brothers? Were disabled and shell-shocked veterans who were unable to return to the work force "feminized" by their incapacitating war experience? How did the discourse of manliness survive the critique of militarism?

It was once an axiom of Marxist ideology that the litmus test for any political program claiming radical credentials was its position on "the woman question." The assumption was that a failure to elaborate an emancipatory program for women was a signal defect that not only debilitated the program as a whole but marked it as one that had not broken with bourgeois values on a fundamental level. ${ }^{2}$ As we shall see, the lines of ideological difference between antimilitarist opponents and bourgeois patriots overlapped when it came to issues of sexual identity, making the "progressiveness" of antiwar representations a contradictory issue. This discovery of politically engaged Weimar artists' complicity with bourgeois attitudes on gender and sexuality scarcely comes as a surprise in light of the similar perspective that critics, especially feminists, have applied to the artistic avant-garde in the last twenty years. My aim, however, is to assess the political implications of works produced by Weimar's foremost antiwar artists and propagandists in order to investigate the historical

see Kathrin Hoffmann-Curtius, “' Wenn Blicke töten könnten' oder: Der Künstler als Lustmörder," in Blick-Wechsel Konstruktionen von Mannlichkett und Werblichkeit in Kunst und Kunstgeschichte, Berlin, 1989, 369-93; and Beth Irwin Lewis, "Lustmord: Inside the Windows of the Metropolis," in Berln: Culture and Metropolis, ed. Charles W. Haxthausen and Heidrun Suhr, Minneapolis, 1990, 111-40. For an insightful essay on the Weimar war imagery of Käthe Kollwitz, see Schmidt-Linsenhoff, and, on Kollwitz's images of proletarian maternity, Joan Weinstein, "Käthe Kollwitz and the Imagery of the Abortion Debate in Weimar Germany," paper presented at the annual meeting of the College Art Association, New York, Feb. 18, 1994. On gender deconstruction in the work of Hannah Höch, see Maud Lavin, Cut with the Kitchen Knife: The Wermar Photomontages of Hannah Höch, New Haven, 1993; and, on Weimar-era female spectatorship, Patrice Petro, Joyless Streets: Women and Melodramatic Representation in Wermar Germany, Princeton, 1989.

2. See Frederick Engels, The Origin of the Family, Prnvate Property and the State 
nature of assumptions about gender and their relation to pacifist, feminist, and patriotic ideology. ${ }^{3}$ The ways in which patriotic ideals of heroism, manliness, and maternity were redefined and deployed in antiwar visual imagery are revealing not only because they complicate claims for the progressiveness of leftist Weimar artists, but also because they provide a better understanding of the ways in which assumptions about gender were contested or incorporated into institutions of war and postwar German society.

The senseless slaughter of World War I signaled neither the demise of militarist ideology nor the end of war mobilization in Germany after 1918. In an attempt to counteract widespread feelings of disillusionment and exculpate the military for the burden of defeat, General Hindenburg effectively placed the blame for Germany's losses on enemies outside and traitors within through the stab-in-the-back theory. By 1922, in violation of the Versailles Treaty, a new secret army had been organized, and by 1924 there were public revelations of a secret rearmament program. At the same time, working-class insurrections, from the November Revolution of 1918-19 through uprisings in 1921 and 1923 were defeated by the Social Democratic government with help from the rightist paramilitary organizations of the Freikorps, setting the stage for the increasingly volatile debate between antiwar forces and nationalists over how to remember World War I. At stake was not only justification for Germany's past but legitimation for a militarized future.

An important aspect of the debate over the war was the question of the heroism of the soldier-male, and related notions of purity and manliness. For pacifists and antiwar artists, the rhetoric of heroism was bitterly ironic; war called forth visions of grotesque and meaningless death, subjective fragmentation, and social chaos, as well as the need, for some, for a new social order. Antiwar artists and propagandists deployed a powerful set of images in order to construct a national collective memory that would serve to prevent future wars. ${ }^{4}$ For patriots, the war conjured up dreams of heroism, national pride and purpose, and visions of a new man and a new nation. ${ }^{5}$ The heroic explanation for the war was meant to produce a version of history that brought honor to the nation based on the central myths that the war was defensive, that German soldiers were pure, and that their deaths were not in vain but served the life of the nation. ${ }^{6}$ According to nationalist rhetoric, purity symbolized moral rectitude and the sublimation of personal needs to a higher purpose, in this case, the survival of the nation. The additional qualities of courage,

(1942), New York, 1975. The original German text was published in four editions between 1884 and 1891. Also see Leon Trotsky, Women and the Family, New York, 1970. This is a collection of articles, speeches, and book excerpts originally published between 1923 and 1936 .

3. For a discussion of gender politics and the Communist Party, see Barbara McCloskey, George Grosz and the Communist Party: Art and Radicalism in Crisis, 1918-1936, Princeton, 1997.

4. For a study of early Weimar antiwar imagery, see Dora Apel, "Cultural Battlegrounds: Visual Imagery and the Tenth Anniversary of the First World War in Weimar Germany," Ph.D. diss., University of Pittsburgh, 1995. For a study focusing on imagery produced during the war, see Annegret JürgensKirschhoff, Schreckensbilder: Krieg und Kunst im 20. Jahrhundert, Berlin, 1993.

5. See George Mosse, Fallen Soldiers: Reshaping the Memory of the World Wars, New York, 1990; and Whalen, 22-25, 27-29. For a discussion of German militarization after the war, see Michael Geyer, "The Militarization of Europe,

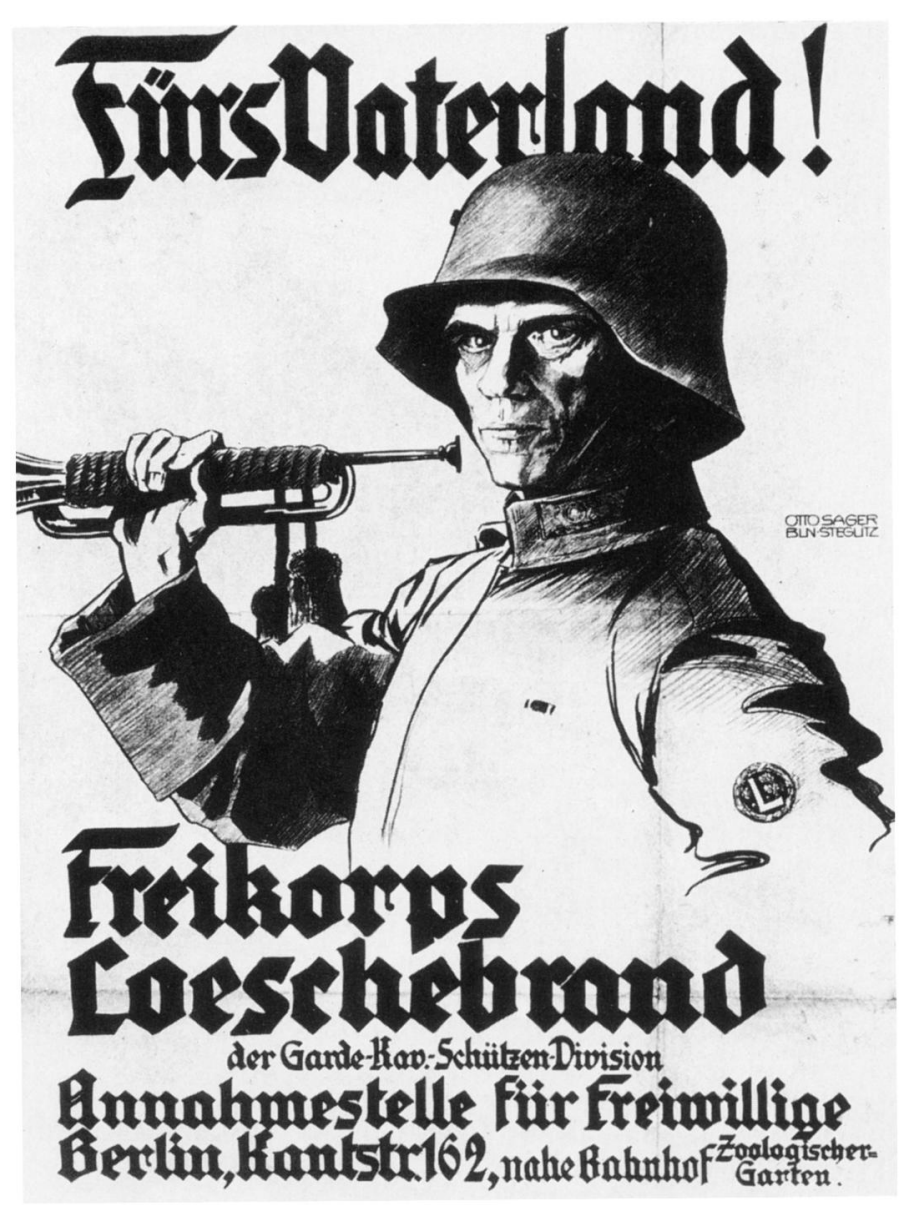

1 Fürs Vaterland! Freikorps Loeschebrand, 1919-20 (from Barbara Mildred Jones, Popular Art of the First World War, London, 1972)

virility, youth, and male beauty derived from Greek ideals constituted the broader concept of manliness. ${ }^{7}$ Manliness, in George Mosse's words, came to symbolize "the nation's spiritual and material vitality," which was central to both "the self-definition of bourgeois society and to the national ideology."8 A recruiting poster of 1919-20 for one of the many rightist Freikorps groups illustrates what the soldier-hero, who emerged as the right-wing vision of the new man, looked like: dominated by the steel helmet, his face and body beneath are hard, taut, and controlled, without emotion or weakness (Fig. 1). He was, in effect, a militarist cyborg, synthesizing biological and technological mechanization. ${ }^{9}$

1914-1945," in The Militarization of the Western World, ed. John R. Gillis, New Brunswick, N.J., 1989.

6. Whalen, 27.

7. On the origins and development of the concept of manliness, see George Mosse, Nationalism and Sexuality: Respectability and Abnormal Sexuality in Modern Europe, New York, 1985.

8. Ibid., 23

9. See Theweleit, 1987 and 1989. For Theweleit, however, in his study of Freikorp literature, the issue is one of purely subjective experience. The male self is armored against disintegration in response to fear of the "female self within." Theweleit's focus on the subjective, psychological experience of the soldier excludes an examination of how that experience was used as an ideological weapon. Also see Matthew Biro, "The New Man as Cyborg: Figures of Technology in Weimar Visual Culture," New German Critique, no. 62, 1994, 71-110. 
Ironically, however, heroic visual imagery was scarce in the early postwar years, perhaps because it was regarded as too discrepant with recent memory. Myths of heroism and manliness were upheld in print and in public celebrations, including speeches by the Social Democratic Party-led government during tenth-anniversary commemorative events in Berlin, when President Ebert reassured the nation that it was only in self-defense that Germany had taken up arms and that the sacrifice of German soldiers had helped Germany to live. ${ }^{10}$ Patriots regarded wartime sacrifice as a form of death that redeemed the dead and allowed them to live again because the nation lived, forming the basis for the postwar cult of the dead. ${ }^{11}$ Myths of heroism and self-sacrifice were also supported by a majority of German historians in the 1920s who rejected the charge that the war was a result of German aggression and perceived their role as that of helping Germans to acquire a national identity by giving them a sense of pride in their past. ${ }^{12}$ Patriots launched fierce rhetorical attacks on pacifist visualizations of the war and right-wing journals such as Deutsche Rundschau regularly published essays that hailed the heroism of the German army, attacked the concept of war guilt as a lie, and suggested that the war was not yet concluded.

The belief in heroism was strong in society at large, providing justification and solace for the families and friends of the millions of men lost or injured in the carnage. ${ }^{13}$ Although many Germans had wearied of the war by 1916 , when the destruction of men and resources beyond what the country could bear became apparent, the "idea" of a just bourgeois war was still accepted in principle and laid the basis for a rejuvenated militarism. The myths of heroism and manliness were advanced above all by officers after the war and differed markedly from the experience most soldiers actually had in the trenches, which had led, for example, to the successful "strike" against the war by soldiers who had refused to return to the front in the last months before demobilization. ${ }^{14}$ The myth of heroism was meant to mask the horror and heighten the glory of war as well as to exonerate the officers' corps from a humiliating defeat that resulted, in large part, from a strategy of attrition. The anniversary year, marking the consolidation of bourgeois rule over proletarian revolt, the relative stabilization of the economy, and the beginning of the decline of the pacifist movement, also marked the high point of antiwar representation. ${ }^{15}$

\section{Gender Identity in the War Imagery of Otto Dix}

Like millions of others, Otto Dix, the son of working-class parents, enthusiastically volunteered for the war in August

10. See, for example, Deutsche Allgemeine Zeitung, Aug. 4, 1924, which carries Ebert's remarks.

11. See Mosse (as in n. 5); also George Mosse, "Two World Wars and the Myth of the War Experience," Journal of Contemporary History, XxI, 1986, 491-513.

12. On German nationalism, see Eric Hobsbawm, Nations and Nationalssm since 1780: Programme, Myth, Reality, Cambridge, 1990; also Richard J. Evans, Rethinking German History: Nineteenth-Century Germany and the Origins of the Third Rerch, London, 1987; and Michael Geyer, "The Stigma of Violence, Nationalism, and War in Twentieth-Century Germany," "German Identity," special issue of German Studies Review, Winter 1992, 75-110.

13. German casualties during the war were estimated at over 2 million dead and over 4 million wounded. See Whalen, 40.

14. See Richard Bessel, "The Great War in German Memory: The Soldiers
1914 at the age of twenty-three; he underwent training as an artilleryman and machine gunner and later saw action on both the eastern and western fronts. When his tour of duty was completed, he again volunteered as an aerial trainee as late as 1918, in order to observe the war from this heightened perspective. Promoted to the rank of master sergeant, he received both the Iron Cross for valor and the FriedrichAugust Medal after being wounded by grenade splinters. Dix's return to the western front as a volunteer aerial trainee at a time when home-front heroization of the "air aces" had cast them as the most glamorous combatants suggests that for Dix, as for German society at large, battle experience had become a central value in defining social status and identity. Indeed, Dix projected a belief in war experience as profound life experience. Almost fifty years after the fact he reasserted his initial attitude toward the war: "The war was a horrible thing, but there was something tremendous about it, too. I didn't want to miss it at any price." 16 This view accepted war as a test of maturity, courage, and masculine prowess, "a supreme experience of life for men who could undertake it." ${ }^{17}$ German historians have remarked on the sense of lost opportunity to prove one's manhood among young Germans of the postwar period who had not fought in the war and who pored over popular books of war photographs-which typically showed heroic battles without picturing any German dead or wounded. ${ }^{18}$ Although Dix, in his postwar imagery, rejected the cult of the fallen soldier whose spilled blood nurtured the living nation, the concept of manliness as a form of sublimated virility and personal heroism was less easily rejected. We might see this as the ideology of militarism versus the ideology of manliness.

During the war, Dix made about six hundred rapid drawings in the same format using pencil, ink, and wash, in a Futuristic-Expressionistic style. Works such as Dying Warrior of 1917 (Fig. 2) illustrate the abstracted force lines concerned with the release of energy, a style closely associated with the war enthusiasm of the Italian Futurists who had first developed it. The adoption of this style by Dix in 1914 marked an ambiguous attitude toward the war, but one tilted toward the romanticism of struggle and infused with Nietzschean notions of creation through destruction.

Dix adopted his well-known satirical style of realist caricature only after the war, to express his opposition to the persistence of militarism in the new republic. ${ }^{19}$ On August 1, 1924, Dix for the first time exhibited his fifty-print War etchings, divided into five portfolios, at Karl Nierendorf's

of the First World War, Demobilization and Weimar Political Culture," German History, vi, no. 1, 1988, 20-34; also idem, Germany after the First World War, Oxford, 1993.

15. Coinciding with the 10-year anniversary of the armistice in 1928, the last years of the Weimar Republic again saw an increased production of commemorative war imagery as part of a renewed campaign to glorify the war. Patriotic photographic albums and films especially were instrumental for the nationalists; antiwar imagery also took the form of films. For a discussion of the debate over the film based on Erich Maria Remarque's important pacifist book, see Modris Eksteins, "War, Memory and Politics: The Fate of the Film All Quiet on the Western Front," Central European History, XIII, 1980, 60-82; also see Bruce Murray, Film and the German Left in the Wermar Republe: From Caligar to Kuhle Wampe, Austin, 1990.

16. Otto Dix, quoted in Dietrich Schubert, Otto Dix mit Selbstzeugnissen und 
2 Otto Dix, Dying Warrior, 1917. Private collection (photo: Otto Dix Stiftung, Vaduz)

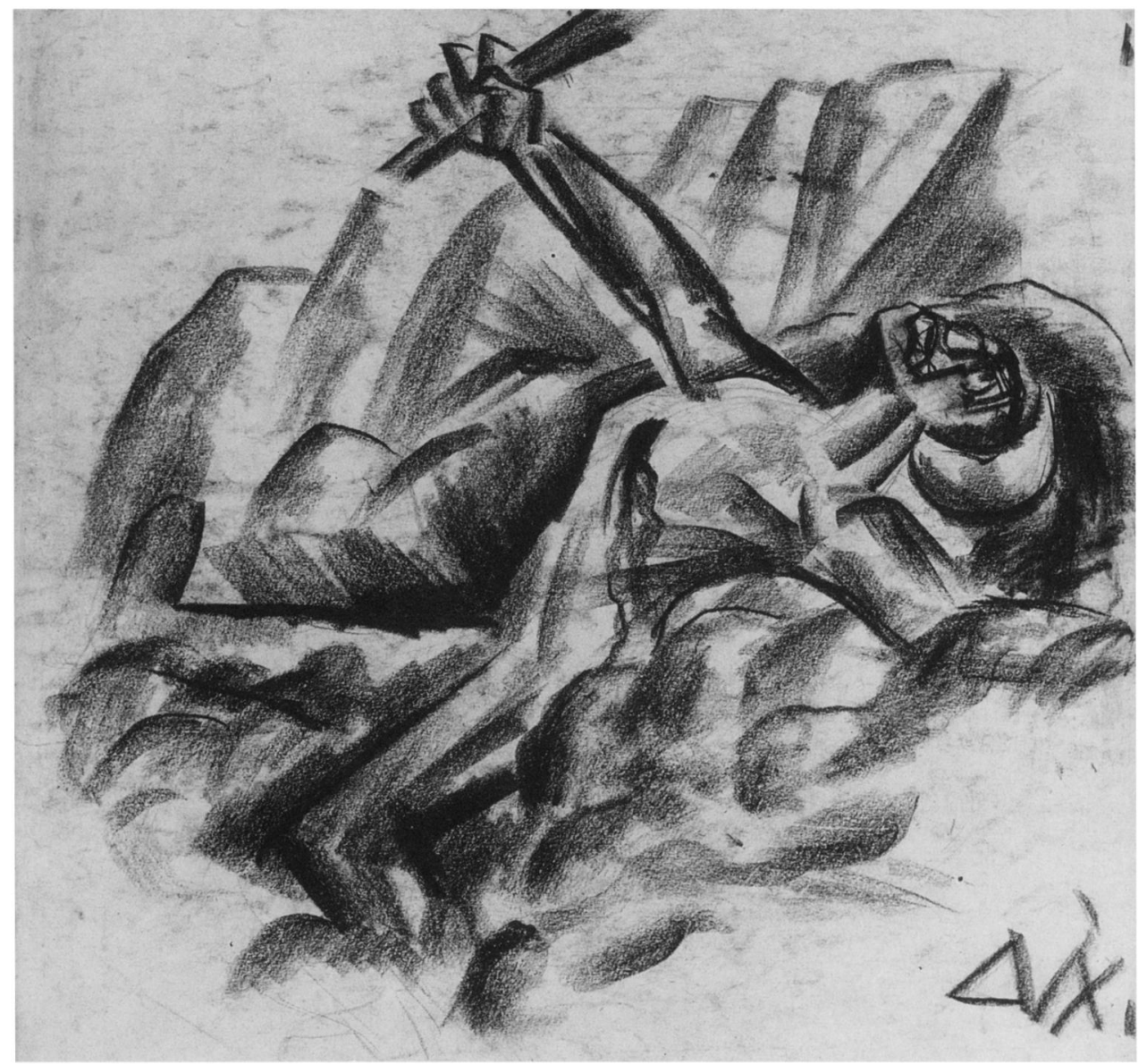

gallery in Berlin. The portfolios unsparingly depict rotting corpses, skeletons, gaunt, wounded, and mutilated soldiers, prostitution, and madness. Unlike Goya's Disasters of War, to which they have often been compared, Dix's etchings focus exclusively on the victims of war; they lack textual commentary, representations of the enemy, or an examination of causes. Many of the etchings bear the names of the places where Dix served, producing the effect of eyewitness accounts of the soldier's daily experience of war. The graphic series was condemned not only by nationalists on the political right, including the National Socialists, but also by bourgeois critics in the art world. In one outraged letter to Nierendorf, a Cologne art dealer called the prints "an effrontery which every former front fighter must take as the deepest insult." 20

In one of these prints, Visit to Madame Germaine's in Méricourt (Fig. 3), Dix portrayed an enormous prostitute together with a slight, one-eyed soldier who is overwhelmed

Bilddokumenten, Reinbek, Germ., 1980, 24, Stuttgarter Zeitung, Nov. 30, 1961: "Der Krieg war eine scheußliche Sache aber trotzdem etwas Gewaltiges. Das durfte ich auf keinen Fall versumen."

17. Geoffrey Best, “The Militarization of European Society, 1870-1914," in Gillis (as in n. 5), 21.

18. See, for example, Hermann Rex, Der Weltkrieg in seiner rauhen Wirklichkeit 1914-1918, Oberammergau, 1926; Franz Schauwecker, So war der Krieg: 200 Kampfaufnahmen aus der Front, Berlin, 1928; Georg Soldan, Der Weltkrieg im Bild, Berlin, 1930; Ernst Jnger, Das Antlitz des Weltkrieges, Berlin, 1930.

19. Dix's paintings and collages of 1920 first demonstrated an antimilitarist stance, as did his connections with other politically committed artists in the early 1920s and his contributions to the radical leftist journals of George Grosz and John Heartfield. He participated in the activities of Willi Münzenberg's Soviet-affiliated International Workers' Aid organization (IAH), collaborated by her. The prostitute is harshly caricatured as a fat, grinning whore covered with lace and flowers, sitting on the lap of the physically subordinated soldier. This satirical representation is linked to a second image of prostitution in the war etchings: Front-line Soldier in Brussels (Fig. 4) represents another frail soldier who surveys corpulent prostitutes on the street wearing expensive, if obscenely revealing, clothes. Though many prostitutes were destitute mothers with numerous children, Dix's prostitutes are bloated from the profits of their commerce in a manner that links them to the common Weimarera portrayal of war profiteers by leftist artists. Dix plays on stereotypes of the prostitute as morally and physically corrupt, her body the site of rapacious sexuality and dominating physicality in inverse proportion to the diminished and disfigured militarized male. The soldier is not only subordinated to the prostitute but implicitly corrupted by the impurity of the transaction. with pacifist and Communist artists in the IAH portfolios Krieg: 7 Originallithographien (War: 7 Original Lithographs) and Hunger, and was a member of the 1924 Communist-organized Red Group of artists. Perhaps most significantly, the introduction to the second edition of Dix's 1924 pamphlet War, based on a selection of prints from his War etchings portfolio, was written by the celebrated French pacifist and author Henri Barbusse. Also see Otto Karl Werckmeister, "German Art in the First World War," manuscript, 1984.

20. This letter was from the proprietor of the Kunstsalon-Centrale für graphische Kunst, a respectable concern in Cologne. Herman Abels to Karl Nierendorf, Nuremberg, Germanisches Nationalmuseum, Archiv Otto Dix, IC 21. Wulf Herzogenrath mentions the National Socialist response in "Die Mappe Der Krieg 1923-24," in Otto Dix: Galerie der Stadt Stuttgart, ed. Wulf Herzogenrath and Johann-Karl Schmidt, Stuttgart, 1991, 74. 


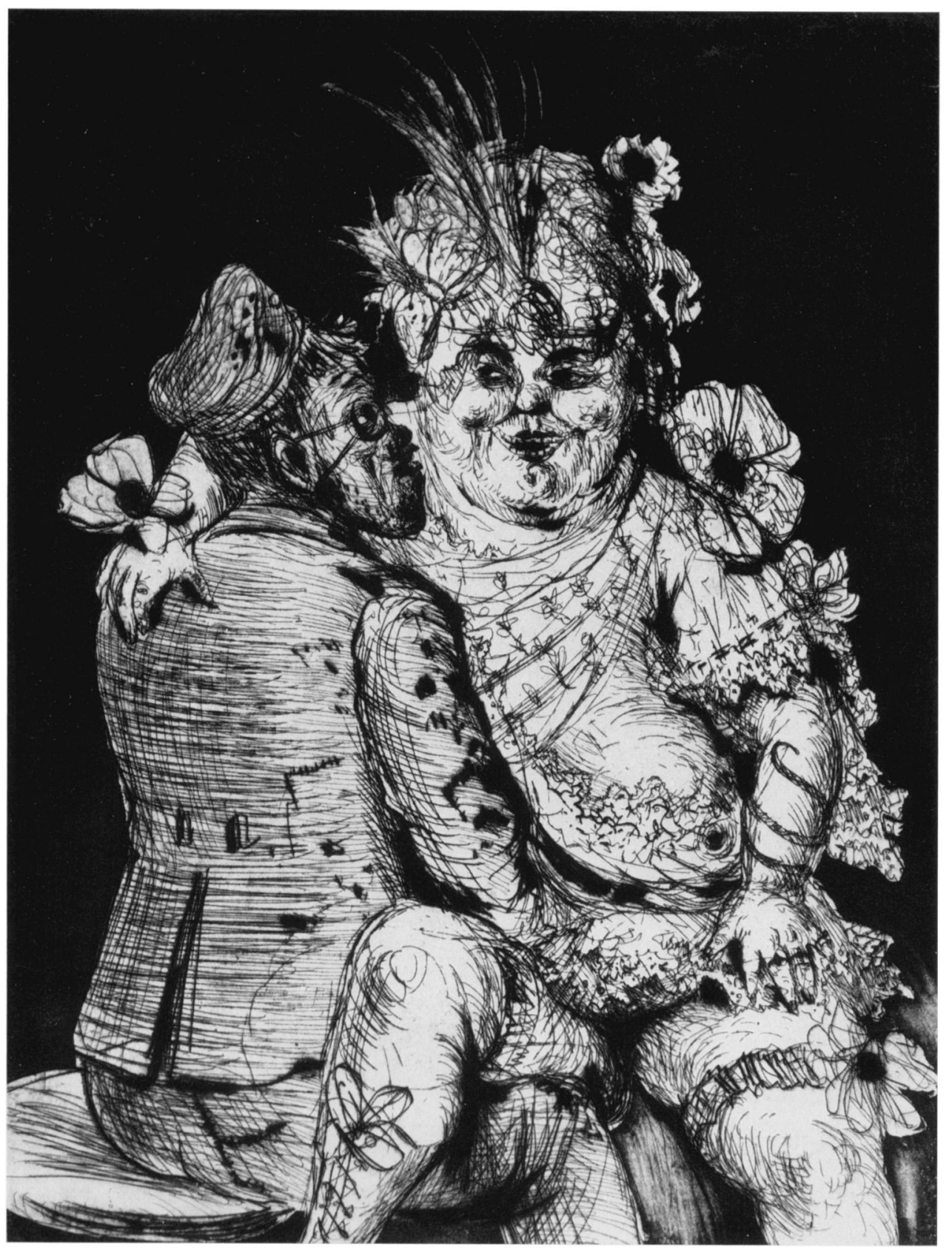

3 Otto Dix, Visit to Madame Germaine's in Méricourt, 1924, from Der Krieg. Los Angeles County Museum of Art, The Robert Gore Rifkind Center for German Expressionist Studies
This issue is reconfigured in Dix's drawing Whore with War Cripple (Fig. 5), in which a jaded prostitute bearing syphilitic sores on her face becomes a paradigmatic representation of the inevitable desiccation and degeneration associated with the unproductive sexuality of the prostitute. In Germany, prostitution was regarded by the government as part of the "problem" of the declining birthrate of the nation. The declining birthrate, in turn, was seen as signifying a national decline. As early as 1915 an official memorandum from the Prussian Ministry of the Interior indicated that the declining birthrate was caused by a cultural decline associated with sexual immorality and the dissemination of birth control. The remedies suggested were material incentives for marriage and children combined with sanctions against prostitution, venereal disease, and fertility control. ${ }^{21}$ Thus, prostitution became a symbol of the degeneration of the nation, and immorality was associated with the "unproductive" or nonreproductive sexuality of the prostitute, perceived as a perversion of woman's basic maternal nature. ${ }^{22}$

The prostitute's companion is a one-eyed veteran with a gaping wound across his face. The pairing of these two figures causes them to be read as homologous, which Maria Tatar has suggested depends on their positions as society's victims, as "casualties of a society that harnesses bodies into service for
21. Usborne, 17.

22. According to the late-nineteenth-century "science" of sexology, women were understood as overwhelmingly sexual beings whose purpose was reproduction. Even Magnus Hirschfeld, the leading sex reformer of the 1920s, though he argued for certain forms of female emancipation from repressive social restraints, reproduced a set of valuations that subordinated women to men and maintained traditional roles for women against their demands for independence and reproductive rights. See Magnus Hirschfeld, The Sexual History of the World War, New York, 1934; also Atina Grossmann, "The New 
4 Otto Dix, Front-line Soldier in Brussels, 1924, from Der Krieg. Los Angeles County Museum of Art, The Robert Gore Rifkind Center for German Expressionist Studies

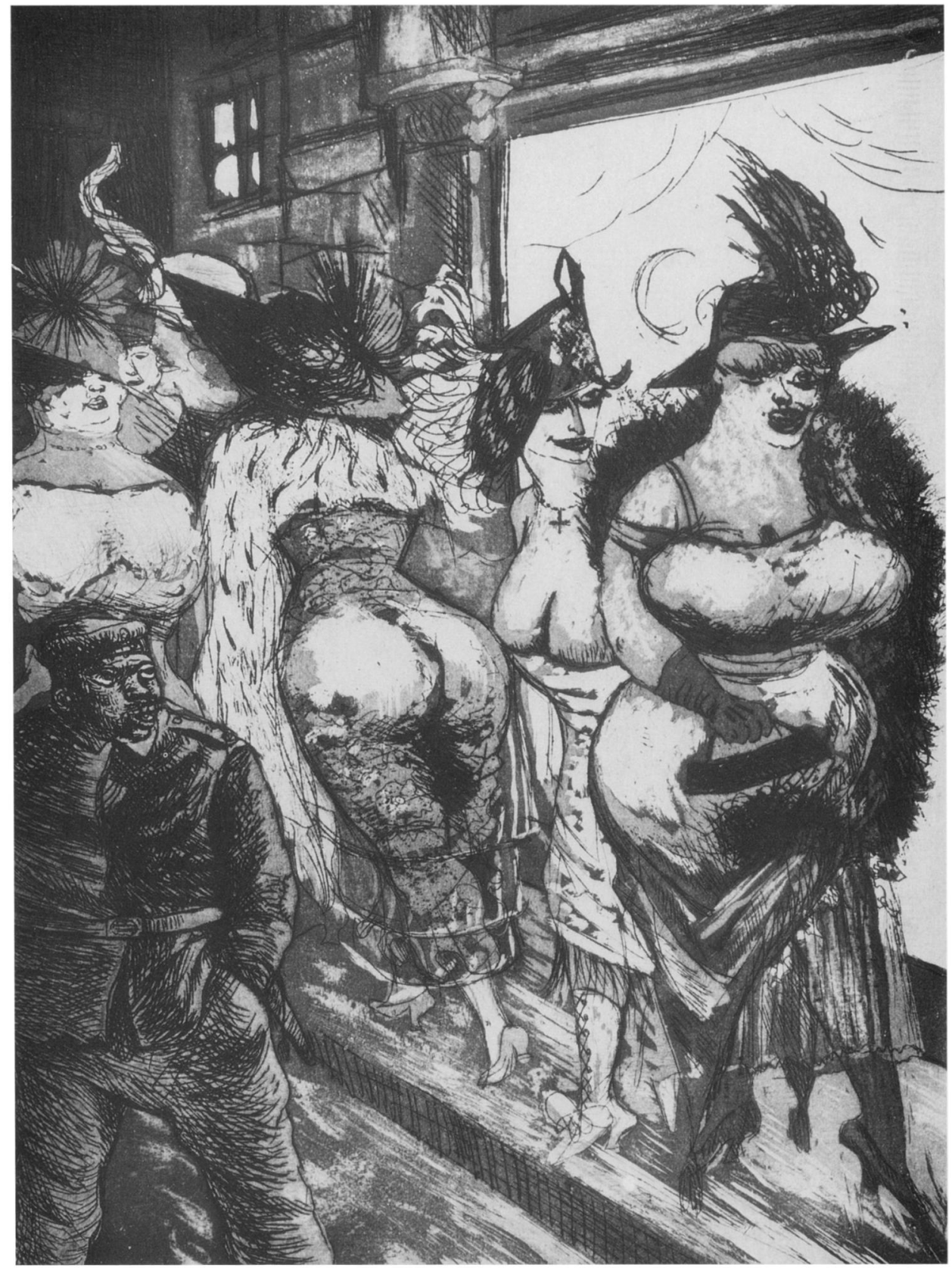

pay."23 Indeed, this drawing was retitled Two Victims of Capitalism, though there is disagreement about whether the title was changed by the editors of the Communist journal Die Pleite, where the image was first published, or by Dix's dealer, Karl Nierendorf. But compassion for victims of social injustice does not account for the brutality of Dix's representations. The view of prostitutes as morally and physically corrupt in all three images of prostitution parallels the representation of male disfigurement as a loss of manliness which is pictured in Dix's etchings either as the domination of afflicted soldiers by prostitutes who prosper-both figuratively and corporeally-at the soldier's expense or as a physical and spiritual parallel between diseased prostitutes and disabled war veterans.

We can read this loss of manliness as a form of "feminization." "Feminization" was counterposed, by the medical establishment as well as the political right, to the notion of the "new man" created in the "steel bath" of war. ${ }^{24}$ The concept of psychic shock found little understanding or acceptance among the military or medical establishment in Germany. With few exceptions, Weimar doctors refused to acknowledge shell shock (today's posttraumatic stress syndrome) as a legitimate war disability, instead regarding it as a form of hysteria, associated with the psychic weakness of women, Jews,

1995.

23. Tatar (as in n. 1), 81 .

24. The new man was also a figure engaged by a broad range of Weimar modernists. See Biro (as in n. 9). 


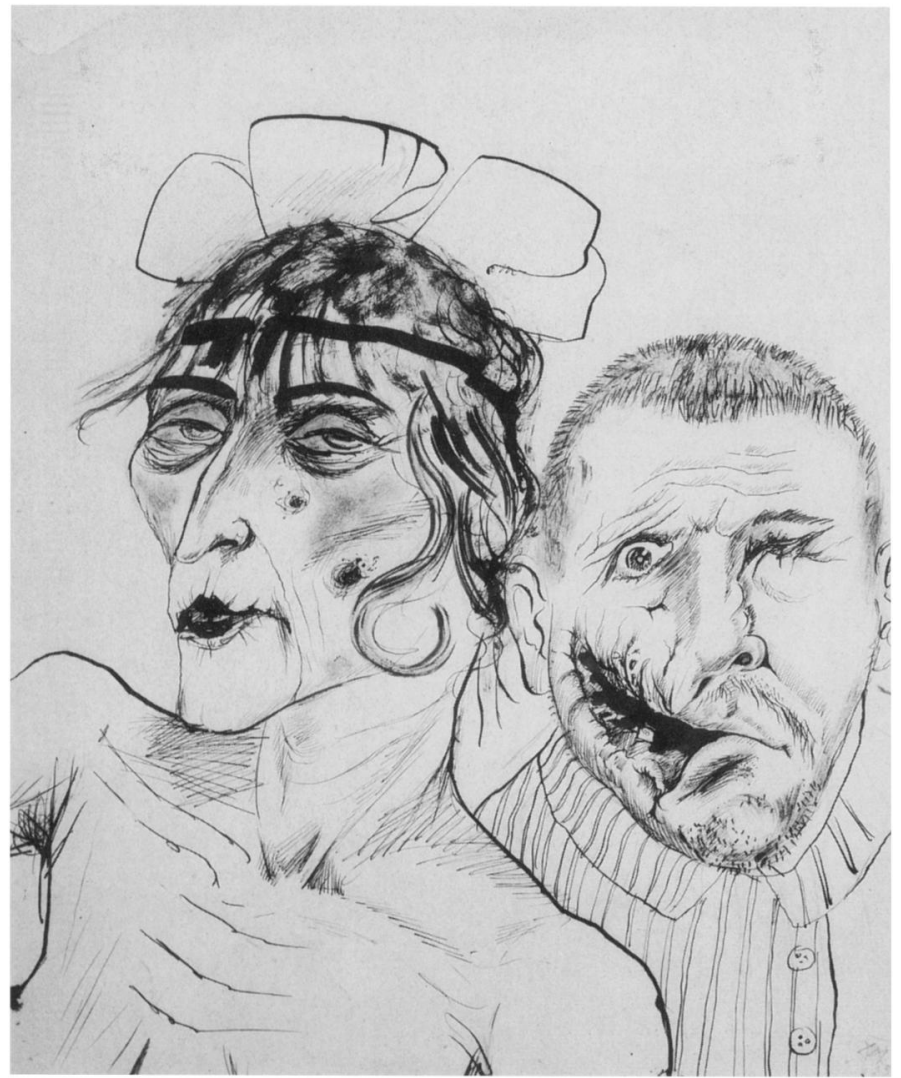

5 Otto Dix, Whore with War Cripple, 1923. Vaduz, Otto Dix Stiftung

and homosexuals. ${ }^{25}$ For the extreme rightists of the Freikorps, the rhetoric of manliness went as far as it could go in constructing an eternally mobilized soldier. Freikorps soldiers aimed to arm themselves against the republic and resurrect the true, militarized "nation." Even the nature of patriotism changed for them, from prewar associations of class and property to a more abstract, metaphysical proposition: individual soldiers came to embody "the nation" in their own inner being in an allegorical fusion of the soldier-male and the "German soul." 26 Since most Freikorps members were drawn from the middle and working classes, their redefinition of patriotism from a class-based to an ideological and sexbased definition of the "German soul" put them on an equal footing with the ranks of officers traditionally drawn from the aristocracy. Committed to the ideal of a military culture, the
Freikorps equated the nonmilitarized male, or civilian life itself, with femininity. ${ }^{27}$

While playing on stereotypes of the weak, disabled soldier and corrupt, rapacious prostitute, Dix also produced a disturbing image to challenge bourgeois notions of purity and respectability in the German soldier-male. His War portfolio initially contained a single image of rape, Soldier and Nun, in which a soldier aggressively brutalizes a nun (Fig. 6). The rape is made more shocking by the soldier's transgression against a conventionally inviolate female. The nun's terror is conveyed by her (barely delineated) deathly face, clawing hands, and bare, splayed legs. By recasting the soldier-male as violent and sexually uncontrolled, Dix problematized the issue of aggression by representing it as repression and displacement of masculine desire. This raises larger questions about the nature of war and conventions of social order that encourage aggression in the context of war. ${ }^{28}$ Nor can the issue of anti-Catholicism be discounted. The individual war diaries discovered on captured or dead German soldiers by the French reveal a fierce anti-Catholicism among German troops, at least some of whom regarded convents and monasteries in Belgium as diabolical places where genital mutilations were practiced on hapless German soldiers. ${ }^{29}$ AntiCatholic feeling, in turn, may be linked with atrocities such as rape in which notions of purity are subsumed by the assertion of masculine prowess against fears of castration and feminization engendered by war as well as a desire to terrorize and humiliate the enemy. ${ }^{30}$ Dix's representation of the hulking rapist also plays on German knowledge of anti-German propaganda depicting the ravaging "Hun" that was produced in abundance during World War I, especially in the United States and Britain, as well as the bellicose militarist view glorifying the Hun that was articulated by the kaiser himself at the start of the war.

Dix's dealer urged him to remove Soldier and Nun along with Visit to Madame Germaine's from the War portfolio. Nierendorf regarded both etchings as dangerously provocative and possible grounds for government seizure of the entire portfolio. In a letter to Dix, Nierendorf wrote,

Yesterday several people told me that the inclusion of the print "Soldier and Nun" would threaten the whole work with confiscation, especially since your depiction of war is in itself a slap in the face for all those who celebrate our "heroes" in the anniversary week and are brimming over with pugnacity and derring-do.... People will make this

History, LXVI, no. 1, 1994, 1-33

30. Rape was defined as a war crime for the first time in 1996 when a United Nations tribunal, the International Criminal Tribunal in the Hague, announced the indictment of eight Bosnian Serb military and police officers in connection with rapes of Muslim women during the Bosnian War. "Experts said that while previous postwar courts have heard evidence of rape, they have treated it as secondary, tolerated as part of soldiers' abusive behavior" (Marlise Simons, "For First Time, Court Defines Rape as War Crime," New York Times, June 28, 1996, 1). After almost 2 years of investigations, the tribunal concluded, in effect, that quantity had turned into quality after calculating that in 1992, 20,000 Muslim women and girls were raped by Serbs as a systematic strategy of terrorization. Also see the debate initiated by Helke Sander's film Befreier und Befreite (Liberators Take Liberties) about the rapes of German women by Russian soldiers during and after World War II, Berlin 1945: War and Rape; "Liberators Take Liberties, " in special issue of October no. 72, 1995. 
one print into the target of all their attacks. Even the print "Soldier and Whore" [Visit to Madame Germaine's] is a slap in the face for all those who have a bourgeois conception of a front-line soldier. ${ }^{31}$

Visit to Madame Germaine's may have raised questions regarding the soldier's manliness, but Soldier and Nun carried the soldier's lack of control to an unacceptable extreme. Dix refused to delete the brothel scene, despite Nierendorf's concern. He agreed, however, to the removal of Soldier and Nun, doubtless the more inflammatory of the two etchings, since it played on anti-German stereotypes and violated all standards of bourgeois respectability. ${ }^{32}$

The Trench, Dix's monumental postwar painting produced between 1920 and 1923, became his most explosive intervention in the Weimar debate between antiwar and patriotic forces. Representing a moment of annihilating defeat, The Trench (Fig. 7), now lost, depicts the aftermath of an overnight artillery assault on a German trench at the western front. The perspective of the viewer is deep in the trench amid the almost tangible smell of death and rotting corpses, looking up at a soldier's body hurled out of the trench and onto metal stakes at its edge. As anticipated, this work was met with controversy when first shown at the Wallraf-Richartz-Museum in Cologne in $1923 .{ }^{33}$ Protests took on national dimensions when the painting was exhibited in the spring exhibition at the Berlin Academy of Art in May and June of 1924. Sympathetic critics called the image "the true essence of war," while Julius Meier-Graefe, a leading critic and champion of French Impressionism, attacked the painting as a "public scandal" that was "not only badly, but also infamously painted, with a penetrating joy in detail" that made the viewer want "to puke." 34 Veterans, pacifists, and leftists who had lived through the war and were disillusioned by the horror of it read in Dix's work a condemnation of militarism and the continued militarization of Weimar society. Veterans and patriots who still embraced the romantic myths of honor and heroism, or who believed in the just cause of the war, saw Dix's work as a tendentious statement that insulted the army and the nation, offering no hope for honor and adding to the tragedy of defeat. ${ }^{35}$ Although Dix intervened in a highly charged political field from a clearly antimilitarist standpoint, ${ }^{36}$ The Trench, like Dix's other antiwar representations, is nevertheless significantly complicated by the way it addresses the crisis of male subjectivity engendered by the war.

The Trench appears to be an image of totalized destruction, yet there exists the suggestion of a literal embodiment of

31. Nierendorf to Dix, July 7, 1924, quoted in Otto Dix 1891-1969, exh. cat. Tate Gallery, London, 1992, 155.

32 . On the role that nationalism played in the development and maintenance of bourgeois respectability, see Mosse (as in n. 7).

33. Dix was given his own room in an upper story, where the painting was hung behind a curtain, which had to be pulled open in order to view the painting. It was explained in a press release that this drastic step was taken so that "no one could say that they were forced to see and experience so upsetting a subject while visiting the museum"; H. F. Secker, press release, Wallraf-Richartz-Museum, end of Nov. 1923, repr. in Schröck-Schmidt, App., 42. On The Trench controversy, see Dennis Crockett, "The Most Famous Painting of the 'Golden Twenties'?”' Art Journal, LI, no. 1, 1992, 72-80.

34. Julius Meier-Graefe, "Die Ausstellung in der Akademie," Deutsche Allgemeine Zeitung, July 2, 1924, repr. in Schröck-Schmidt, App., 73.

35. See Schröck-Schmidt for a thorough discussion of this debate.

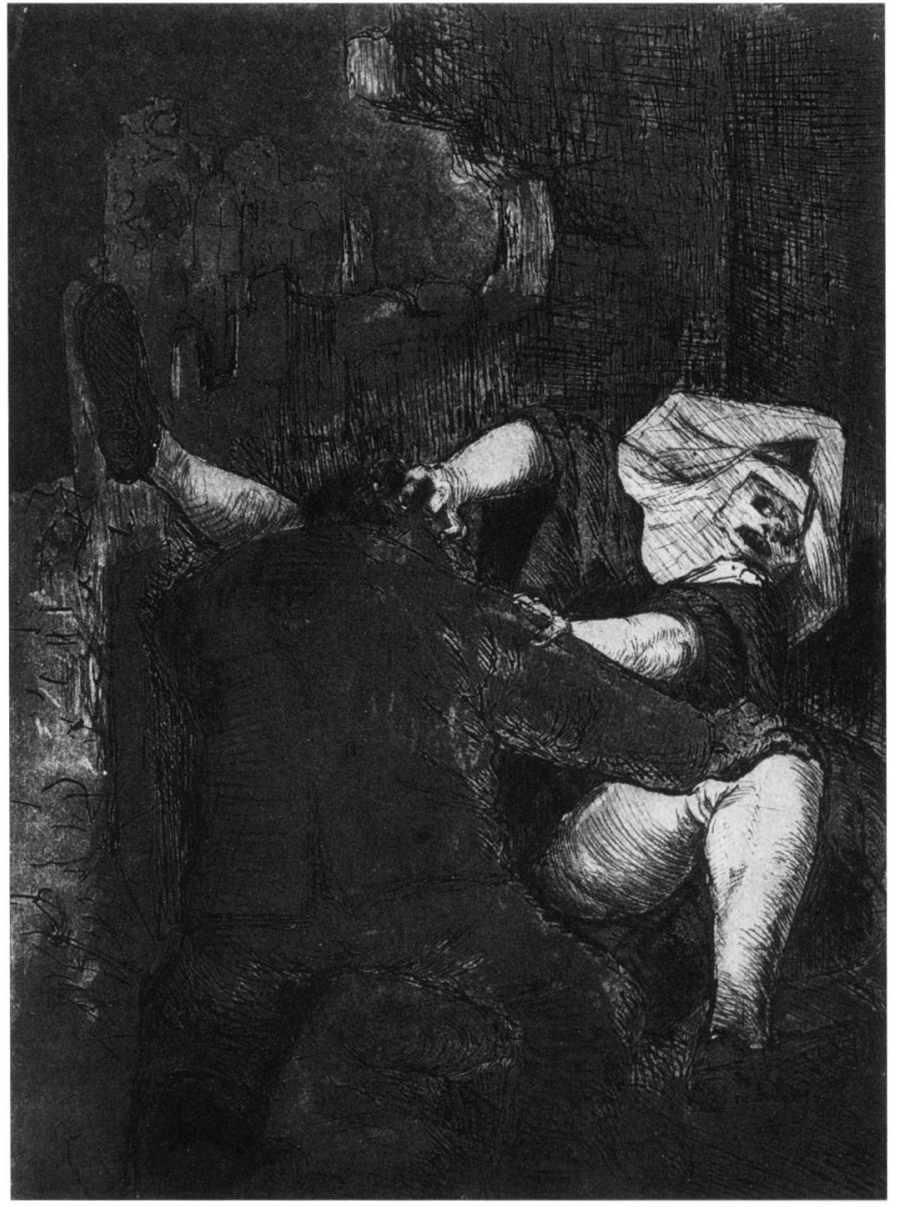

6 Otto Dix, Soldier and Nun, 1924. Vaduz, Otto Dix Stiftung

manly virility in the spectacle of the martyred figure impaled at its edge. Physically lifted above the devastation and compositionally highlighted by his isolation, we find at the center of this prone figure, where his genitals should be, not one but two vertical protrusions: one is the blade of a bayonet, the other-perhaps the handle of a knife-another phallic reference. Dix thus provides the soldier-male with an apparent symbolic erection at the moment of his death, equating sexual potency with the warrior's heroism by doubling the representative phallus with the bayonet blade and implying the sublimation of one into the other-the essence of purity. At the same time, an ironic reversal is implied: the proximity of blade and phallus insinuates the specter of castration and the loss of both masculinity and humanity. The slightly

36. Attempts have been made by some critics to separate the painting from its historical context and confine it to a psychological meaning, that is, as a therapeutic exercise for Dix. See reviews in Gustav Eugen Diehl, "Ausstellung Otto Dix; Katalog mit Verzeichnis der gesamten Graphik bis 1925," Veröffentlichungen des Kunstarchivs nos. 2-3, 1926; more recently, see Otto Conzelmann, Der andere Dix: Sein Bild vom Menschen und vom Krieg, Stuttgart, 1983, and the response to Conzelmann's assertions of the apolitical character of Dix's work in Dietrich Schubert, "Otto Dix und der Krieg," in Pazifismus zwischen den Weltkriegen: Deutscher Schriftsteller und Künstler gegen Krieg und Militarismus 1918-1933, ed. D. Harth, Heidelberg, 1985, and idem, "Betrifft: O. Conzelmann, Der 'Andere' Dix: Brief an die Redaktion einer KunstZeitschrift," Kritische Berichte, XII, 1984, 84-94; Conzelmann's approach is shared by Matthias Eberle in World War I and the Weimar Artists: Dix, Grosz, Beckmann, Schlemmer, New York, 1985. 


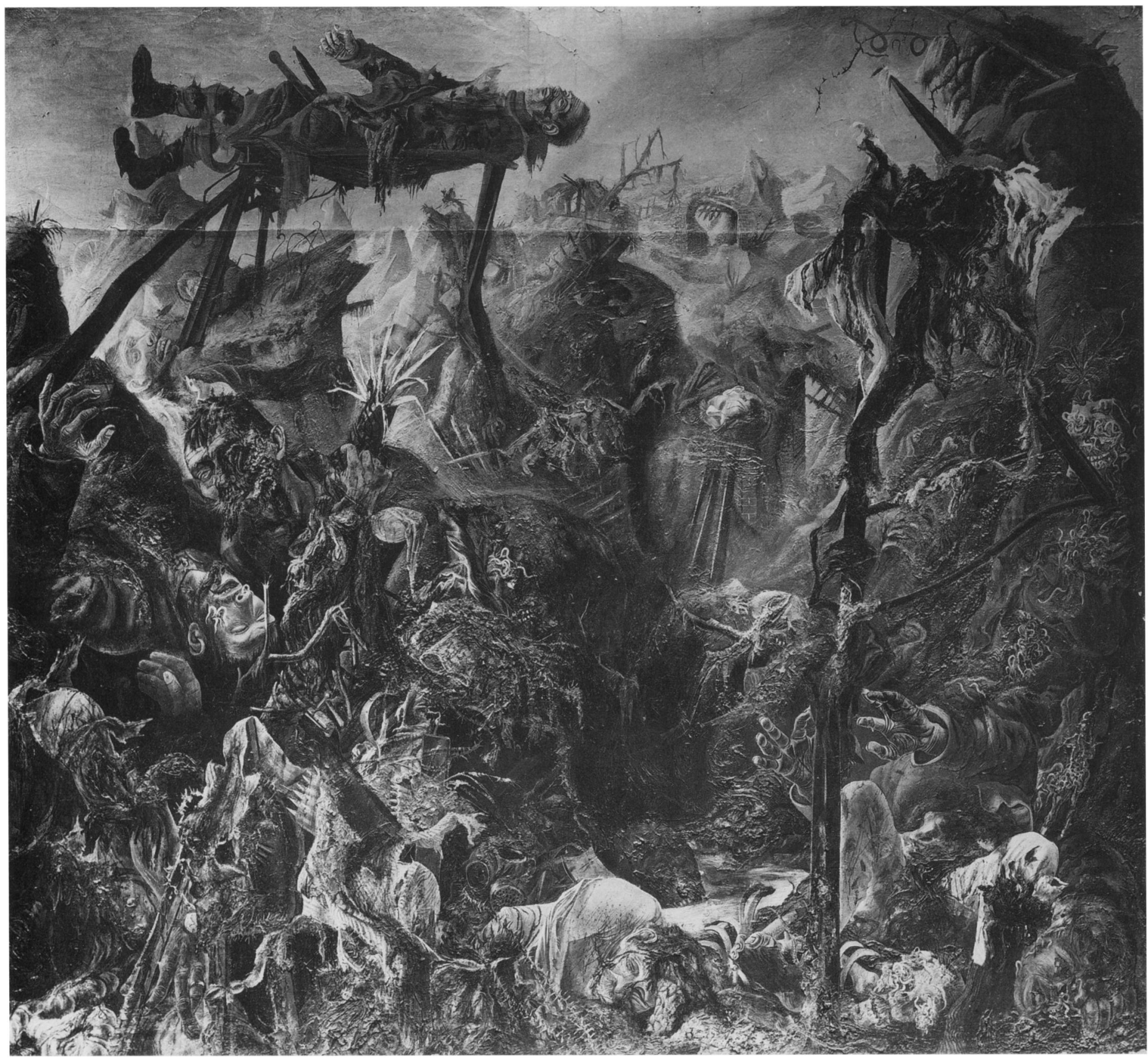

7 Otto Dix, The Trench, 1920-23. Location unknown. Vaduz, Otto Dix Stiftung

upraised arm and closed fist may be read as a last affirmation of courage at the moment of defeat, a heroic, if futile, gesture that echoes the now useless phallus and is reinforced by the tension and rigidity of the body frozen in rigor mortis. Dix employed a similar motif in Dying Warrior (Fig. 2), in which the warrior's upraised arm, still clenching a weapon, and his out-thrust chest are the last heroic gestures of a mortally wounded soldier as he sinks down to the earth.

Despite Dix's postwar alliance with the antiwar movement and his reputation as Germany's foremost antiwar artist, his representation of trench warfare, like his depiction of a valiant dying warrior, projects a continued ambivalence toward war experience that was present in the very different wartime drawings. In The Trench, Dix reintroduces elements signifying the discourse of manliness into an otherwise horrific image of war. These elements were ignored by contemporary critics and have gone unremarked by subsequent art historians, who have debated the painting's pacifist stance or the aesthetics of its chilling veristic style. Yet these signs of sexual/social identity, as forged through front-line experience, are not separate from the political implications of content and style; on the contrary, the postwar understanding of the soldier's identity was central to interpreting the meaning of the war itself. The shift in meaning between phallic references and weapons imagery alludes to the larger ambiguity of how to understand the masculine experience of war. The virility of the martyr highlights personal heroism and manliness, while the technology of war signifies death and defeat.

Dix's work did not reject but redefined, in visual terms, the 
nationalist notion of manliness, from patriotic self-sacrifice that served the birth of a new nation to a subjective, if failed, test of endurance and strength of character. While the gendering of war as male was of course not invented by Dix but was a precondition established by military policy, he created a tension between assumptions about manliness and assumptions about militarism. In The Trench, virility is not a sign of national honor but a victim of the devastating effects of industrialized war on the male body, visualized as the real field of battle. Even as individual death is made into a display of masculinity, individuality itself is made meaningless by the industrial killing power of modern warfare, which causes grotesque and anonymous death in the form of mass annihilation ${ }^{37}$-far different from the patriotic myth of a dignified burial for each soldier. The figure of masculine endurance and phallic assertion thus becomes endowed with the futility characteristic of the lone gesture. Raised above the mass of mutilated bodies in the trench, the prone figure signifies both personal strength and communal failure. It is a kind of sacrificial offering that, by virtue of its bodily integrity, throws into sharper relief the wreckage below, which itself betokens the magnitude of destruction.

Dix opposed the consequences of militarism and the nationalist ideology that supported it, offering stark and shocking evidence of its meaningless devastation; yet he also played on stereotypes of the new man. In his 1924 pen-andink self-portrait drawing This Is How I Looked as a Soldier (Fig. 8), Dix portrayed himself with a bullet hole in his helmet and a torn uniform, while holding a machine gun with grim-faced determination. The position of this drawing, in which Dix presents himself as a knowing participant, as the frontispiece to his War etching series served to authenticate the artist's authoritative stance as a war veteran. The implicit assertion that "he was there" was designed to establish the veracity of his pictorial observations and stand them against all challenges, political or aesthetic. ${ }^{38} \mathrm{He}$ depicts himself as a willing belligerent, replete with the cynical, hardened face of the "soldier-hero" who familiarly wields his lethal weapon-a veteran who has survived, physically and psychologically, the challenges to masculine identity posed by war. It may also be read as a sly self-parody, in which Dix conveys his own complicity and ironically comments on the controlled mechanization of the war combatant, the cold brutality of the seasoned soldier-male.

At the same time, however, the bravado of the postwar soldier's identity was consistent with the view of a number of opponents of the war who deplored the barbarity of warfare but did not reject the idea of war as a life experience of enormity and greatness, a view Dix himself later expressed. A telling comparison can be made between the manly swagger of This Is How I Looked as a Soldier and the ludicrous pretensions of the old soldiers in War Cripples (Fig. 9), in which a parade of limbless veterans whose bodies are mechanically held together with a variety of prosthetic devices flaunt their war medals in a grotesque display of militarist pride. Dix

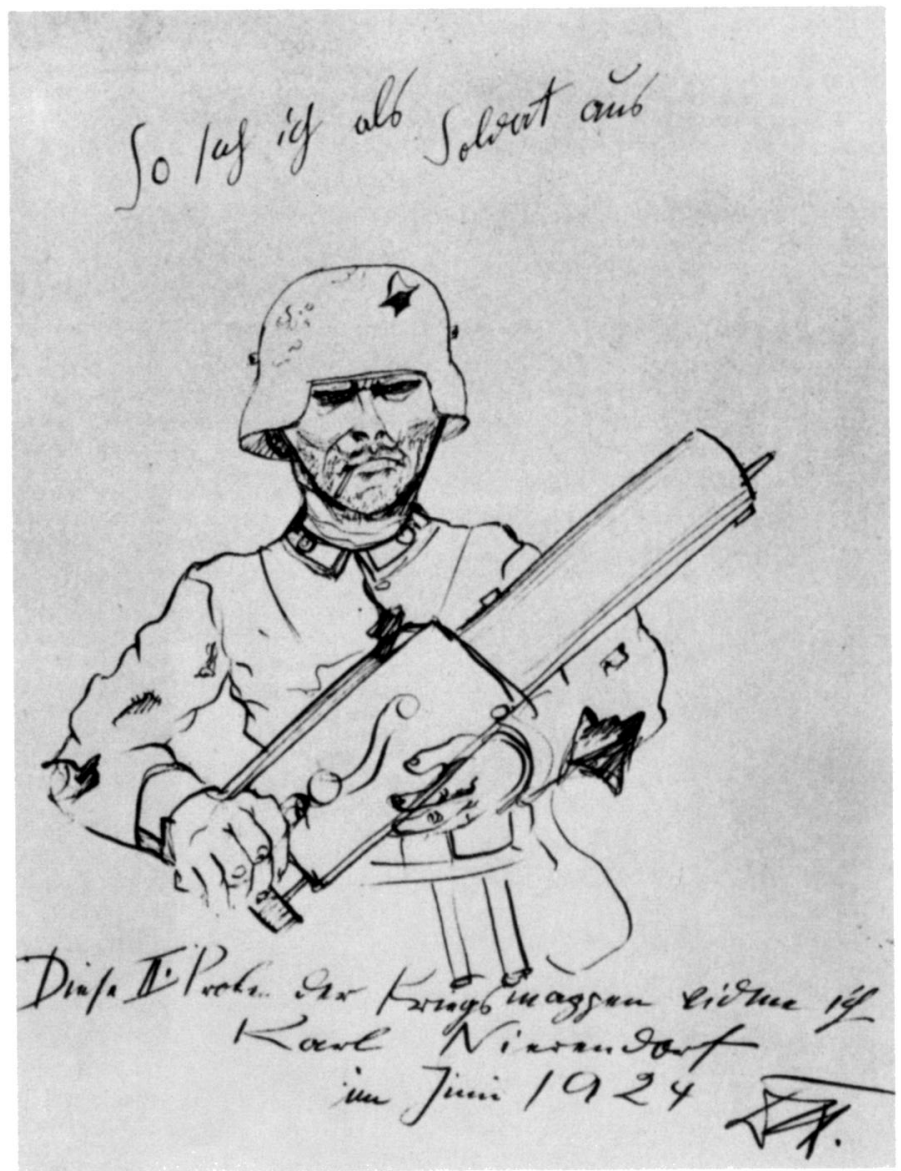

8 Otto Dix, This Is How I Looked as a Soldier (So sah ich als Soldat aus), 1924. Collection of Bettina Dix-Pfefferkorn. Vaduz, Otto Dix Stiftung

reportedly subtitled his work Four of These Don't Add Up to a Whole Man. ${ }^{39}$ This observation alludes to the irreparable fragmentation of the body caused by war and also addresses the issue of "manliness" in the soldier-male. The image may be read as a parody of manliness, a portrait of "feminized" physical ruin that Dix himself had narrowly avoided. Or Dix may be asserting a highly ironic form of "mechanized" masculinity, in which virility is transformed into prosthetic hardware. However ironically, Dix toyed with notions of feminization in such depictions of disabled veterans and in representations of wounded soldiers with prostitutes; likewise, he played on stereotypes of manliness by asserting the masculinity of the front-line soldier in The Trench and by authenticating his role as a warrior in This Is How I Looked as a Soldier.

\section{The Militarized Female and the Prostitute in War against War!}

In the same year that Dix's War etchings debuted in Berlin, another set of images entered the antiwar debate. On the occasion of the tenth-anniversary commemorative events in
37. For an insightful discussion of this issue, see Bernd Hüppauf, "Experiences of Modern Warfare and the Crisis of Representation," New German Critique, no. 59, 1993, 41-76.
38. Werckmeister (as in n. 19), 59 .

39. Conrad Felixmüller manuscript, Jan.-Feb. 1920, quoted by Eberle (as in n. 36$), 44$ 


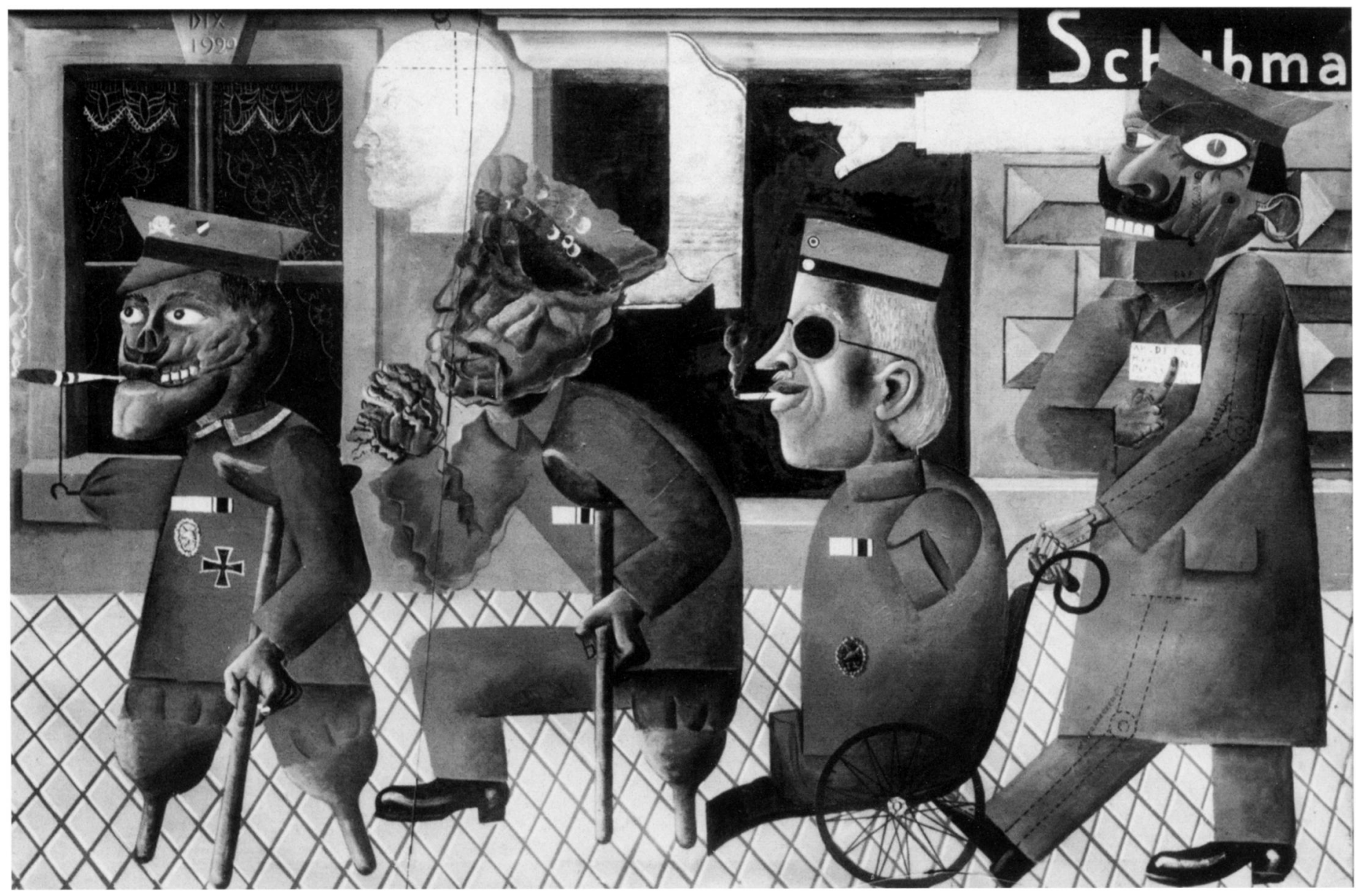

9 Otto Dix, War Cripples, 1920. Location unknown. Vaduz, Otto Dix Stiftung

1924, the anarcho-pacifist Ernst Friedrich published Krieg dem Kriege! (War against War!), an antimilitarist photographic narrative in four languages. ${ }^{40}$ Coinciding with its publication, Friedrich exhibited in his International Antiwar Museum in Berlin enlarged images from the book, in addition to prints from Dix's War portfolio and the seven woodcuts from Käthe Kollwitz's War series, produced in 1923. Friedrich not only assembled pictures of the horrors of war, including decaying corpses and mutilated bodies, he also juxtaposed them with his own ironic and partisan captions. The book became an instant sensation, eliciting angry demands from patriotic veterans' organizations and conservatives that it be banned and Friedrich exiled from Germany, ${ }^{41}$ as well as praise from such leftist writers as Kurt Tucholsky, who suggested, "Whoever sees these [photographs] and does not shudder is not a human being, but a patriot." 42 By 1930 War against War! had been translated into more than forty languages and had gone through ten editions.

Toward the middle of the book, War against War! reprints a government proclamation exhorting the soldier to carry on the great military traditions of Germany with a quotation

40. Ernst Friedrich, Krieg dem Kriege! (1924), Frankfurt, 1992. The book was reprinted in Weimarer Republik, exh. cat., Kunstamt Kreuzberg und dem Institute für Theaterwissenschaft der Universität Köln, Berlin, 1977.

41. The Bavarian Soldiers' League (Bayerischen Kriegerbundes) appealed to the Munich public prosecutor's office in Feb. 1925 to ban the book; its from the kaiser:

Just as one thousand years ago the Huns under their King Attila made a name for themselves that to the present day has left evidence of their power in traditions and legends, so also may the name "German" be made so dreaded through you for a thousand years, that no one in the future will ever dare again to look askance at a German. ${ }^{43}$

This is followed by two photographs of women. The first displays the slain body of a raped Russian woman with her pants torn away from her genital area; three soldiers stand on a rise behind her (Fig. 10). The caption reads, "Violated woman's corpse. (This was the case of a woman belonging to the Russian Battalion of Death, who wore a man's uniform)." 44 The woman is identified as a "legitimate" enemy target through her membership in the Russian Battalion of Death. Although this would be sufficient to explain her murder, it would not necessarily explain her rape. To this end, presumably, Friedrich adds the observation that she "wore a man's uniform." Since the institution of war was gendered as masculine both ideologically and pragmatically, the fact of the

appeal was printed in the Königsberger Volkszeitung, no. 96, and quoted in Friedrich's own newspaper, Freie Jugend yr. 7, no. 5, [March 1925]. The same issues of these papers also reprinted an editorial first published in the München-Augsburger Abendzeitung by a rightist named Traub, who called not 


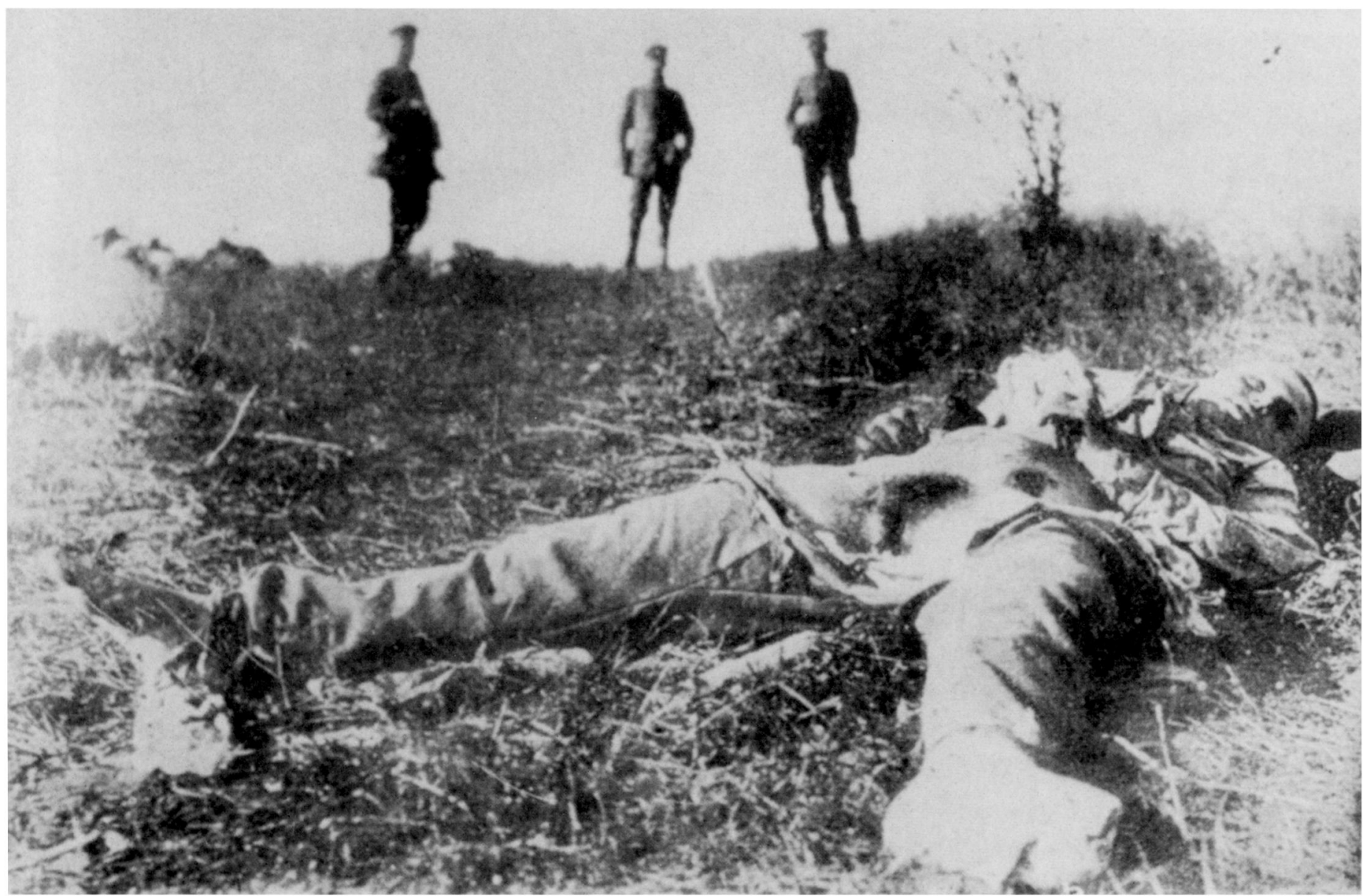

10 "Violated woman's corpse. (This was the case of a woman belonging to the Russian Battalion of Death, who wore a man's uniform," from Friedrich, War against War! 1987, p. 179 (reproduced by permission of the Anti-Kriegs-Museum, Berlin)

uniform being a "man's" might be taken for granted. Yet Friedrich spells it out, marking the category of "soldier" as masculine once again. For what purpose? While her murder as a soldier in the Russian Battalion of Death may be understood as "justified," as a woman who "wore a man's uniform," Friedrich seems to imply, her rape may be understood not simply as a wartime abuse but as a kind of punishment for a different sort of hostility, that is, for the transgression of gender boundaries. Friedrich employs the photograph as an example of a wartime atrocity and a tragic result of the discourse produced by the kaiser's militarist rhetoric; yet his remark about the woman's uniform may be read as a backhanded explanation of the "extenuating circumstance" that, though it does not justify her shameful violation, helps to explain it.

The second photograph is a two-page spread in the 1924 text showing three Germans in civilian dress (the one in the center wears a German helmet) standing behind four young, topless Belgian prostitutes (Fig. 11). The caption reads, “German 'heroes' in Belgian brothels. ('And German culture shall some day regenerate the world')." 45 The photograph is

only for banning the book but also for prosecuting Ernst Friedrich and his newspaper and expelling Friedrich from the country.

42. Kurt Tucholsky, "Waffe gegen den Krieg," in Gesammelte Werk, II, 361-62. It first appeared in Die Weltbühne, Feb. 23, 1926. followed by a German document concerning the "Rules and Regulations for the control of the brothel in MünchenGladbach." 46 It details the grueling schedule of two working prostitutes who are "restricted" to one client every quarter hour from 5:30 P.M. to 9:00 P.M., that is, 20 men per evening between them, or 120 per week, "so as not to demand of the women a labour that exceeds their capacities." The document includes a schedule of battalion assignments to the brothel for Monday through Saturday and notes that there will follow other regulations "regarding 'individuals' [i.e., officers] who have the right to enter if the women are not occupied." Like Dix, Friedrich seems to challenge the myth of the German soldier's "purity"; at the same time, Friedrich exposes the hypocrisy of the German state in allowing the military establishment officially to regulate and control foreign brothel schedules while deploring the practice at home.

The photograph of bare-breasted Belgian prostitutes presents the subject for its voyeuristic value even as Friedrich morally condemns the practice of prostitution. However, he condemns it not only on the grounds of the control of foreign women by the German military but also because it was a
43. Friedrich, 178.

44. Ibid., 179 .

45. Ibid., 180

46. Ibid., 181. 


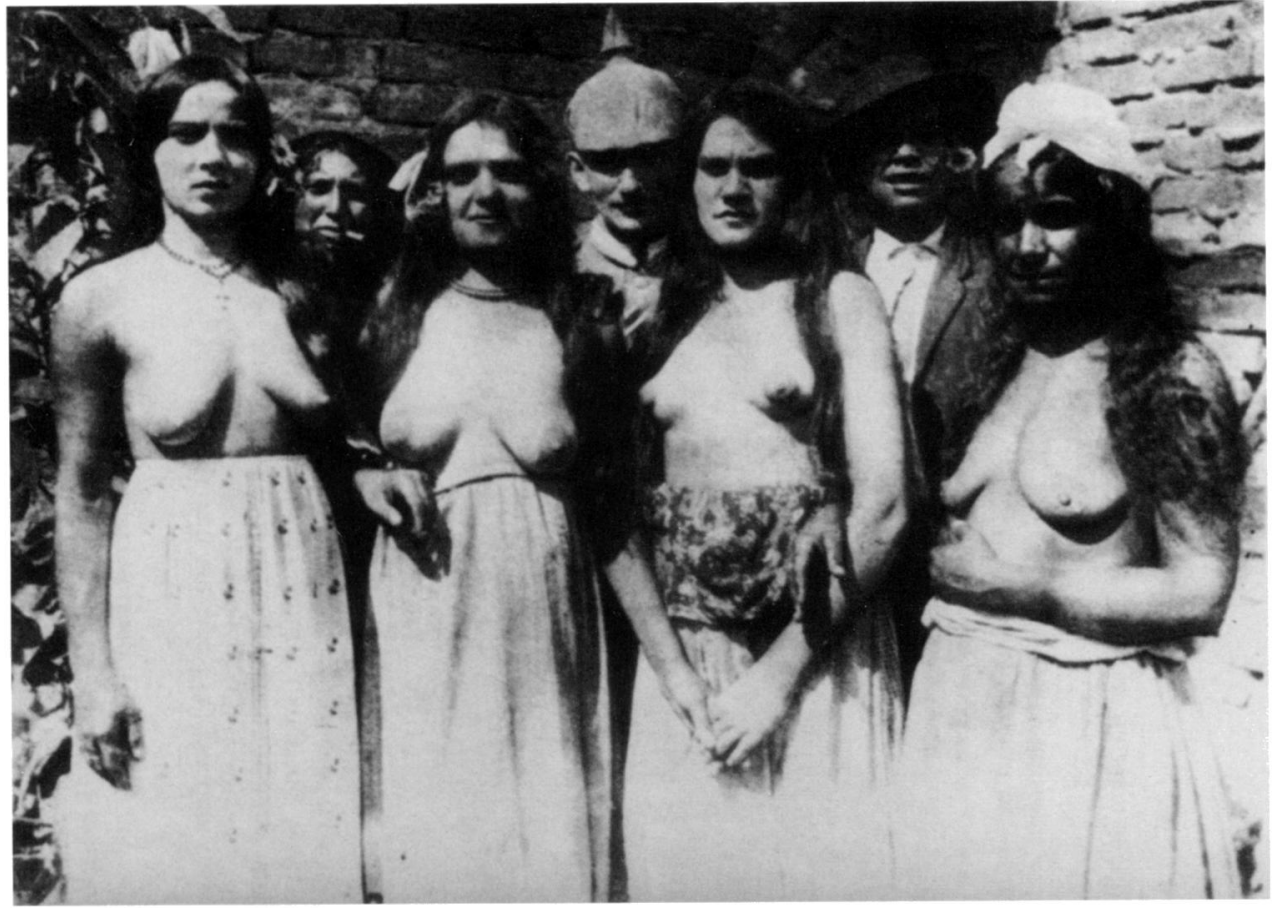

11 "German 'heroes' in Belgian brothels. ('And German culture shall some day regenerate the world')," from Friedrich, War against War! 1987, p. 180 (reproduced by permission of the Anti-Kriegs-Museum, Berlin) corrupting influence on German patriarchal culture, as indicated by the sardonic, parenthetical remark, "And German culture shall someday regenerate the world." It is the prostitutes who are constructed as "impure," according to bourgeois codes of respectability, and the men, the bearers of culture, who are made so only by association with them. The implication is that as long as German men are corrupted by consorting with prostitutes, German culture shall never "regenerate the world." Friedrich's rhetorical strategy reinscribes the dominant view that prostitution symbolized the degeneration of the nation. By critiquing the military tradition of organized prostitution as a morally "contaminating" influence on the soldier, Friedrich incorporates bourgeois respectability into the pacifist discourse and his antimilitarist stance in part depends on a naturalization of the notion of German male purity and the immorality of nonreproductive sexuality.

Just as men were corrupted by prostitutes in a moral sense, they were also victimized in a physical sense by women as the "carriers" of venereal diseases. The sex reformer Magnus Hirschfeld, while pointing out that class issues of poverty were often operative in driving women into prostitution, also pronounced prostitutes to be innately degenerate. Hirschfeld further implicated all women as the carriers of venereal disease, while men were posited as its victims. The reference in the document on brothel regulations to the privileged access to prostitutes enjoyed by officers further points to class differentiations according to which officers went without any medical checkups while ordinary soldiers were subjected to

47. Hirschfeld (as in n. 22), 183

48. Theweleit, 1989, 15-17.

49. Friedrich, 28.

50. Ruth Roach Pierson, “' 'Did Your Mother Wear Army Boots?': Feminist Theory and Women's Relation to War, Peace and Revolution," in Images of Women in Peace and War, ed. Sharon Macdonald et al., Houndmills, Eng., 1987, 217; also see Joyce Berkman, "Feminism, War, and Peace Politics: The Case of genital exams on a regular basis. As a consequence, the incidence of venereal disease was much higher among officers, and the prostitutes whom they infected, according to Hirschfeld, were often forced to submit to brutal treatment in venereal disease hospitals. ${ }^{47}$ In some cases, medical treatment of infected women was considered useless, as it was believed that infected women were used as a weapon against the German army. Such women were evacuated and interned for the duration of the war. In one case, in 1916, at least fifteen hundred women from the German-occupied French towns of Lille and Roubaix were indiscriminately and forcibly transported by railway freight cars marked "vegetables" to other small French towns. ${ }^{48}$

\section{The Pacifist Address to Women}

Though the photographs in War against War! include neither the home front nor the collaborative role of German women in the war, in his introduction, conclusions, and captions, Friedrich directly addresses women in their role as reproducers and protectors of life. Parents are exhorted not to let their children play with war toys and women are called on to actively prevent their husbands from entering war service. Friedrich ends his introduction with the call, "Mothers of all lands unite!" 49 Mothers are regarded as the motor force of history and moral suasion as an adequate substitute for social, political, and economic power in this perversion of Karl Marx's famous phrase. Friedrich's slogan sought to "awaken” women to their true interests in opposing war as a way to protect their families. Precisely because mothers were in-
World War I," in Women, Militarism, and War: Essays in History, Politics, and Social Theory, ed. Jean Bethke Elshtain and Sheila Tobias, Savage, Md., 1990.

51. "Richtlinien des deutschen Bundes für Mutterschutz," Die neue Generation, no. 18, 1922, 287-88, quoted in Amy Hacket, "Helene Stöcker: Left-Wing Intellectual and Sex Reformer," in When Biology Became Destiny: Women in Weimar and Nazi Germany, ed. Renate Bridenthal et al., New York, 1984, 123-24. 
nately peaceful, even if not yet conscious of their inner desire for peace, they were, according to Friedrich, subject to greater moral responsibility for the war. This view reinscribed the traditional division of labor by sex in which aggression was structured as masculine and peacefulness as feminine; it further posited the institution of the family, rather than organized political struggle, as the primary site and means of resistance to the militarization of society. It was therefore necessary for the natural pacifism of women to "tame male pugnacity." 50

Behind the gender-essentialist rhetoric of pacifism was an ideology of motherhood that was central to mainstream organized pacifism, which itself operated primarily to put pressure on the Social Democratic Party (which also enjoyed a majority of women's votes). The Federation for a New Fatherland (Bund neues Vaterland), for example, which dedicated itself to "pacifism and to the struggle against fascism and injustice," was founded on the hope of protecting and encouraging motherhood in order to foster the psychological transformation needed to overcome the will to war. The guidelines adopted by the federation in 1922 described its ultimate goal as "The triumph of motherliness, which expresses itself in love and cooperation, victory of a view of life and the world that overcomes hatred and barbarism through reason and love." 51 The pacifist view of maternity was part of a larger consensus in the Weimar Republic, stretching from social democracy to the political right. This consensus was based on a belief in the importance of the patriarchal family and the notion that women had a duty to act as guardians of the national body. While the right founded its views on motherhood on the need to fight immorality and preserve the family, the Social Democratic Party (SPD) addressed itself primarily to public health and social welfare.$^{52}$ Clara Bohm-Schuch, editor of the middle-class SPD women's journal Die Gleichheit (Equality) and an SPD Reichstag representative, called for educational institutions to instill "the will to maternity" in the younger generation of women in order to serve the nation. In speeches and newspaper essays, Bohm-Schuch repeatedly asserted the special responsibility of women to oppose war, declaring, for example, "The question here is the triumph of a new higher spirit of morality over the old time and its false gods. But our girls and women are called before all to be the banner carriers." 53 The call for a return to maternity and morality based on maternity reinforced conventional bourgeois sexrole divisions at a time when women were seeking broader educational and occupational opportunities.

What the pacifists and Social Democrats failed to explain was how the overwhelming majority of Social Democratic and feminist women in Germany and Europe, and eventually the United States, came to support World War I and reject the idea that women were naturally inclined to favor peace. Gertrud Bäumer, the leading figure in the Federation of

52. Usborne, 17 .

53. Clara Bohm-Schuch, "Völkerfrieden," in Nie wieder Krneg, Sozialistischen Arbeiter-Jugend, Bezirk West-Sachsen, Leipzig, n.d. [1924].

54. Evans, 128.

55. Ibid., 150.

56. Ibid., 77; also see Cornelie Usborne, “" 'Pregnancy Is the Woman's Active Service': Pronatalism in Germany during the First World War," in The Upheaval
German Women (Bund deutsches Frauen), the bourgeois wing of the feminist movement, with more than 250,000 members, condemned pacifism and internationalism as early as 1910 as "outmoded"; in 1917-18, while campaigning for female suffrage, the Federation of German Women issued formal rejections of all proposed armistice terms. ${ }^{54} \mathrm{~A}$ majority of feminists at the start of the war argued that mothers, in particular, had a natural desire to defend their children and that this should be expressed on a larger scale as support for the war and defense of the nation. The mainstream movement in Germany further organized a special campaign to persuade women to have children by propagating the idea of a "Woman's Year of Service" to the nation as the female equivalent of conscription. ${ }^{55}$ The argument that women underwent dangers and sacrifices in childbirth similar to those of men who performed military service was part of the argument for the female right to vote, first promulgated by the Social Democrat August Bebel. ${ }^{56}$ Despite the fact that Friedrich's moral exhortations aimed at women presupposed that women had helped to sustain the war effort through passive acceptance or resignation, the role of women in actively sustaining the war effort was left unexamined and unopposed, as this would have meant critically examining the policies of the Social Democratic Party with which organized pacifism allied itself.

The pacifist argument, by constructing women as guided by "reason and love" to a position of peacefulness, not only ignored the proactive militant stand taken by a majority of women in the war but also denied the conscious political opposition organized by such women as Rosa Luxemburg, Clara Zetkin, and also Karl Liebknecht in Germany. Moreover, the active physical participation of women in the war was concealed by this perspective. Though not true of German women during World War I, hundreds of Russian, Polish, and Balkan women donned military uniforms and entered the medical corps as well as the fighting ranks, a fact to which Friedrich himself alludes in his caption for the raped and murdered Russian woman. In 1917, for example, Russian women joined both Bolshevik forces and the counterrevolutionary Black Hundreds. ${ }^{57}$ The pacifist discourse occluded the fact that it was class interest, not an innate female repulsion to violence, that determined women's political loyalties and the political roles they chose to play.

While the mythology of motherhood concealed the differentiated positions historically taken by women in relation to war and violence, the construction of women as wives and mothers also occluded other identities. Women as wage laborers, for example, were excluded from the pacifist discourse. This is not surprising, since Friedrich did not direct his program to the working class per se nor call for such tactics as working-class strikes against the war. Friedrich

of War, ed. R. Wall and J. Winter, Cambridge, 1988, 389-416.

57 . Women have fought in many other countries since then. In the $1980 \mathrm{~s}$, for example, women enlisted in the rebel Sandinista movement in Nicaragua and in Afghanistan while today, most European and American women support a strong national military establishment and women are entering the military in unprecedented numbers. See Berkman. 
further evaded the issue of the postwar antagonism between men and women that was created by job competition. With the demobilization of soldiers at the end of the war, thousands of women were removed from their wartime jobs to make way for returning men. Tensions were at a high point in 1924, intensified by the hyperinflation and unemployment that peaked during the winter of 1923-24. The appeal to women as reproductive-rather than socially productive-figures naturalized their position in the home at a time when they were forced out of the job market. Also excluded from the pacifist address to women were the middle-class female white-collar workers who largely constituted the Weimar "New Woman." Discursively constructed as masculinized and unmaternal, the New Woman allegedly lacked a desire for children, which linked her to other excluded categories of identity such as prostitutes and lesbians. The idealization of motherhood in the 1920s occurred at a time when women had in fact begun to delay motherhood and bear fewer children as a means of achieving greater social advancement while participating in public life and politics to a greater degree than previously. ${ }^{58}$ The fear of the contaminating influence of the prostitute was therefore not only a projection but also a reflection of an emancipated femininity that had begun to challenge prescribed gender roles. ${ }^{59}$ The gendered discourses of maternity and manliness can be seen as material effects of the social contradictions produced by the capitalist division of labor in Weimar Germany. As such, the concepts of maternity and manliness attempted to mediate these social contradictions.

\section{Käthe Kollwitz and the Pathos of Maternity}

By the time World War I ended in 1918, the fifty-one-year-old Kollwitz was the best-known socialist artist in Germany. She was the granddaughter of an 1848 revolutionary and a loyal supporter of the Social Democratic Party. Her early success as an artist was based on her 1897 etchings of the 1880s weavers' uprising in Silesia, which pictured women participating in acts of political defiance and revolt. World War I, however, proved to be a critical test of her commitment to socialism. Though often represented in art historical literature as a staunch antiwar artist, when the SPD voted for war in 1914, Kollwitz resigned herself to the war's necessity and even admired the selfless idealism of youthful war volunteers, giving her approval to her second son, Peter, when he wished to volunteer. Despite Peter's death in the first months of the war, Kollwitz openly opposed the call for more young volunteers only in the last stages of the war, in response to German poet Richard Dehmel's appeal in October 1918 for a last-ditch patriotic sacrifice. But even this was a circumscribed opposi-

58. See Usborne.

59. Here I differ with Theweleit, who sees the contaminating influence of the prostitute only as a male projection, without further analysis of the social history.

60. Käthe Kollwitz, Vorwarts, Oct. 30, 1918, quoted in Hans Kollwitz, ed., The Diary and Letters of Käthe Kollwitz, trans. by Richard Winston and Clara Winston (1955), Evanston, Ill., 1989, 88-89.

61. The portfolio Kreg: 7 Onginallithographien was published by the Künstlerhilfe, the artists' wing of International Workers' Aid, and also contained works by George Grosz, Otto Dix, Willibald Krain, Otto Nagel, Rudolf Schlichter, and Heinrich Zille.

62. Karin Hausin, "The German Nation's Obligation to Heroes' Widows of World War I," in Behind the Lines: Gender and the Two World Wars, ed. Margaret tion. Kollwitz declared in an open letter of protest, "There has been enough of dying! Let not another man fall! Against Richard Dehmel I ask that the words of an even greater poet be remembered: 'Seed for the planting must not be ground." "60 This quotation has been cited often by scholars as evidence of Kollwitz's fervent pacifism. The preceding portion of her letter, however, reveals that her "pacifism" was significantly qualified: "I respect the act of Richard Dehmel in once more volunteering for the front, just as I respect his having volunteered in the fall of 1914. But it must not be forgotten that Dehmel has already lived the best part of his life. ... A world war did not drain his blood when he was twenty." Like most of German society, Kollwitz did not oppose the idea of war in principle. What she objected to was losing the flower of Germany's youth, those who had not already "lived the best part" of their lives. Accordingly, her prewar representations of assertive, inspirational, or revolutionary women such as the female figure of insurrectionary zeal in The Weavers or Black Anna urging on the peasants in The Peasant Revolt were never refigured, though there was no lack of working-class insurrection at the end of the war and in the early 1920s. Instead, they were replaced by tragic proletarian mothers whose images depended on stereotypes of women as reproducers and protectors of the young, Goethe's "seed for the planting."

Typical of Kollwitz's postwar work is her lithograph The Beggars, part of a pacifist portfolio published in conjunction with the tenth-anniversary events of $1924 .{ }^{61}$ The Beggars focuses on the home-front victims: proletarian women and children (Fig. 12). Three generations are represented: an old woman, whose lined face shrinks into her cloak while she timidly holds out a bent, arthritic hand; a younger woman, with downcast eyes and a prematurely aged face whose large hand is meant to emphasize the manual labor of the proletarian; and a child, sheltered between the two, eyes wide with hunger. The women beg not only for themselves but for the child who is entirely dependent on them and in need of protection; the innocence of the child is meant to arouse a greater sympathy in the viewer for both child and protectors.

The black cloaks of the women indicate that they are probably war widows struggling to exist on state-sponsored pensions. As inflation pushed the value of German currency from 4.70 marks to the dollar in 1919 to 4.2 billion marks per dollar in November 1923, the fixed income of a widow's pension, usually inadequate from the beginning, became negligible. With no marketable skills in an economy already marked by high unemployment, many widows were forced to rely on charity to supplement their inadequate pensions. These pathetic female figures make a direct appeal to the

Higonnet and Patrice Higonnet, New Haven, 1987, 140.

63. For discussions of the War portfolio see Schmidt-Linsenhoff; also see Jürgens-Kirchhoff (as in n. 4), 279-313.

64. Many proletarian women did, however, assert their opposition, leading strikes against the war and demanding to have their basic needs met. During the starvation winter of $1916-17$, which was a turning point in provoking opposition to the war, demands for bread and peace were put forward through political strikes, food protests, and food appropriations carried out by poor women. The militancy of working-class women, noted in many police reports, led to strikes at armament factories in Mannheim and Brunswick, where three-quarters of the workers fined for strikıng against military orders were women. Munitions strikes by women also occurred in Jan. 1918 as part of the 
viewer, evoking sympathy and pity across political lines for women who were reduced to begging. This image alludes to the larger social problems of homelessness, starvation, inflation, and unemployment, the widespread poverty and deprivations that were not officially recognized as part of women's sacrifice during the war. In the gendered hierarchy of war, women were instead perceived as suffering for the glory of their heroic sons and husbands, their own lives "blocked from view" by the "pathos of hero worship." 62 Though a number of artists, including Otto Dix, George Grosz, and Heinrich Zille, represented the despair of home-front victims or veterans and their families in their images of the early 1920s, it was primarily Käthe Kollwitz who was most successful in making visible the suffering of the exploited and oppressed sector of German women who were neglected or abused by government social policy.

At the same time, however, The Beggars plays on stereotypes of proletarian women as helpless, pathetic, and passive victims. Kollwitz depicted similar themes in her 1923 War portfolio, which focused on the pain and sorrow of those left behind during the war, represented by generalized paradigmatic figures of mothers, widows, young volunteers, and grieving parents. ${ }^{63}$ Kollwitz effectively transformed her postwar art into an engagement with the hardships and cruelties of motherhood in images that portrayed working-class women as downtrodden, long-suffering maternal icons. While evoking empathic maternal identification and charitable compunctions, such works also constructed an image of the proletarian woman that no longer posed a threat to the bourgeois social order presided over by the Social Democrats. ${ }^{64}$ Kollwitz continued to support the SPD after the war, despite occasional misgivings; like the SPD, she, too, abandoned her belief in revolutionary politics. ${ }^{65}$

In her pacifist imagery, Kollwitz simplified the political complexities she acknowledged in her diaries and abandoned depictions of the active participation of women, even in representations of organized pacifist resistance. One of her two most publicized antiwar images was The Survivors (1923), a lithograph made into the poster The Survivors - War on War! (Fig. 13) for Antiwar Day on September 21, 1924, an event sponsored by the Social Democratic International Federation of Trade Unions. Though The Survivors-War on War! uses the militantly antiwar slogan of the workers' movement, it is less militant in visual content than her more famous Never Again War (Nie wieder Krieg) poster produced in 1924 for an SPD German youth conference in Leipzig, which uses the more passive pacifist slogan (Fig. 14). The Never Again War poster represents a shouting figure with an upraised arm, a gesture

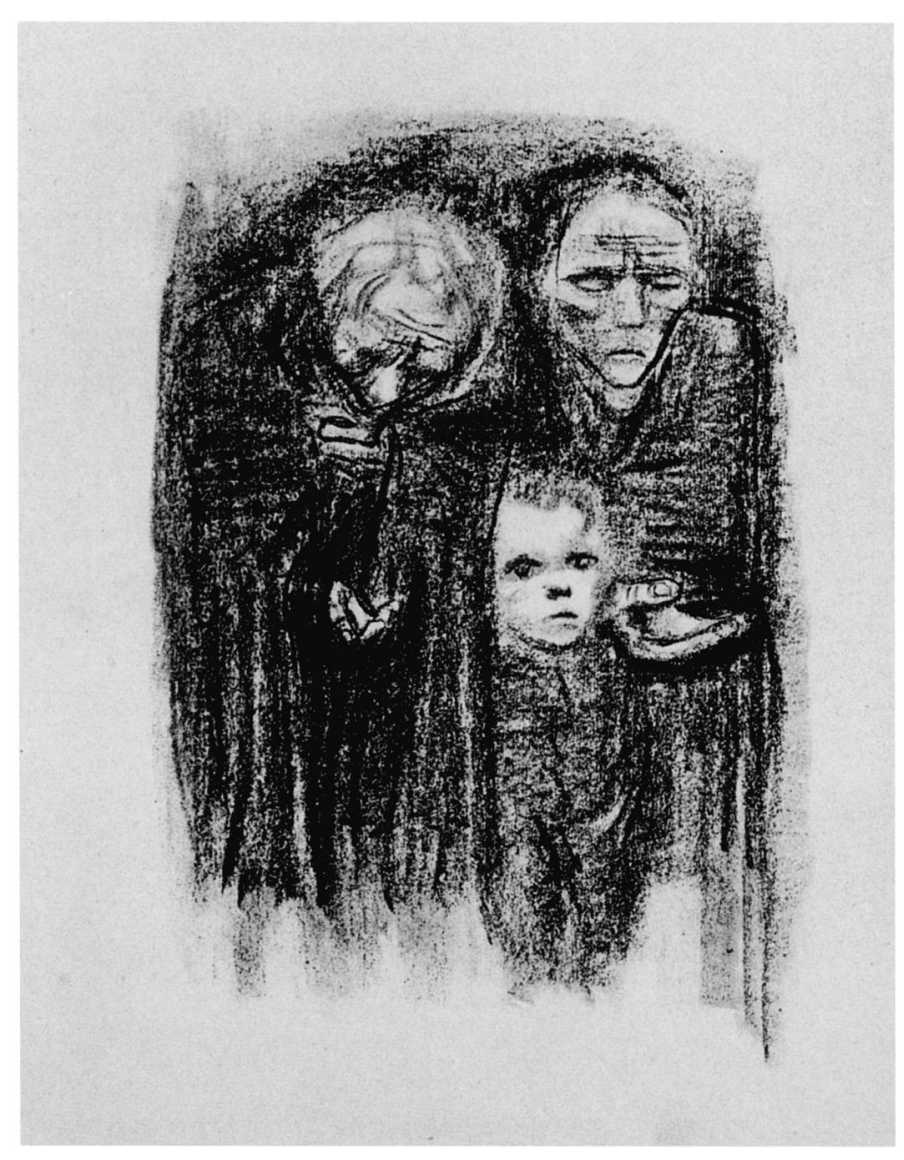

12 Käthe Kollwitz, The Beggars, 1924, from Krieg: 7 Originallithographien (photo: Deutsches Historisches Museum)

in the tradition of freedom fighters during the bourgeois revolution of 1848, that is, aggressively activist and selfconfident. Though this figure may appear androgynous to our eyes, it has been characterized as male by all commentators, probably on the basis of the husky upraised arm and the blown back short hair. In contrast to this militant figure, the Survivors poster portrays despair, deprivation, unresolved loss, and injury in the forlorn countenances of blinded veterans, old men, and small children, who surround the central figure of a tragic proletarian war widow with a face that is barely more than a death's head. Kollwitz described her Survivors drawing in similar terms in a letter to a friend: "Old people, widows, the blind, surrounded by children with their anxious, inquiring eyes and pale faces." 66

The Survivors poster represents a clear-and clearly passive-feminine stance. This image fit in very well with the popular protest that culminated in the November Revolution of 1918-19. Though no women were involved in the central institutions of the revolution, the Workers' and Soldiers' Councils, the food riots by women effectively helped juxtapose the preservation of the family and social autonomy against institutionalized militarization. See F. L. Carsten, War against War: British and German Radical Movements in the First World War, Berkeley, 1982, 148-65, and Evans, 145-49.

65. Kollwitz's diaries make it clear that she did not support the November Revolution and afterward distanced herself from artists' organizations that were affiliated with the German Communist Party. The murders of Liebknecht and Luxemburg were recorded in one brief line in her diary, juxtaposed with a commentary on her vote in the elections, the first with female suffrage, for the
SPD. The motives for her 1921 woodcut Memorial to Karl Liebknecht are not clear, although she indicates in her diary that her political convictions did not correspond to Liebknecht's; the image may be read as a depoliticized homage to a fallen working-class leader. The title inscribed on the work reflects her loss of socialist commitment: "The Living to the Dead. Remembrance of January 15, 1919." Transposing the title of Friedrich Freiligrath's poem of the 1848 revolution, "The Dead to the Living," Kollwitz alters the work's political meaning, suggesting that the living are no longer called on to carry on the struggle, but only to mourn the dead.

66. Käthe Kollwitz to Beate Bonus-Jeep, early 1923, in Beate Bonus-Jeep, Sechzig Jahre Freundschaft mit Käthe Kollwitz, 1948, quoted in Otto-Nagel-Haus, exh. cat., Staatliche Museen zu Berlin, Berlin, 1985, 63. 


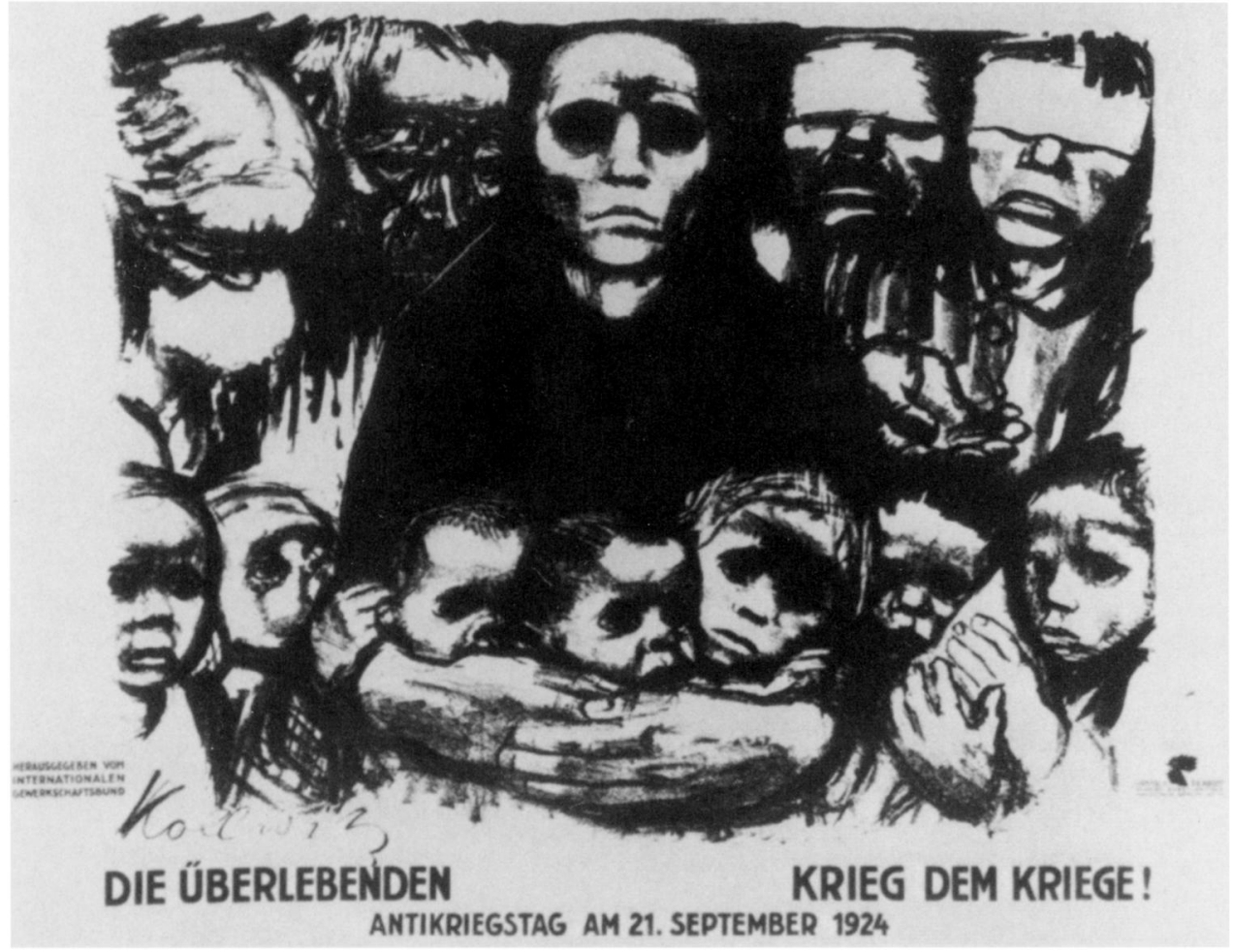

13 Käthe Kollwitz, The Survivors-War on War! (Die Überlebenden-Krieg dem Kriege!), 1924 (from Renate Hinz, ed., Käthe Kollwitz: Graphics, Posters, Drawings, New York, 1981) plans of the International Federation of Trade Unions to tame the militant thrust of the antiwar movement when it took control of the movement in $1924 .{ }^{67}$ The masculinization of the rebellious adolescent who embodies radical pacifism in Kollwitz's Never Again War poster, on the other hand, may be read as a gesture of emotional distance from the militant perspective it represented. ${ }^{68}$ Kollwitz recorded her political disillusionment in her diary:

The youth organizations have all established sensational platforms and appear very pretty and nice, but what they speak about seems downright foolish. I always marvel when young people are pacifists en masse. Only an igniting spark is needed to fall among them and their pacifism is forgotten. The communist labor youth are more honest; they want struggle and war. The war has only exchanged overcoats-instead of black-white-red it is red. ${ }^{69}$

Her Survivors poster, while capable of evoking sympathy and compassion for the victims of war, represents segments of society that are nearly powerless in their attempts to pose a serious threat to the processes of militarization. Kollwitz's prints of the early 1920s seem to reject any notion of female assertiveness by effectively idealizing the traditional motherly qualities of patience, sorrow, and self-effacement, even as the

67. The federation, which commissioned Kollwitz to create the poster, specified that it represent war victims and survivors. See Martha Kearns, Käthe Kollwitz: Woman and Artist, Old Westbury, N.Y., 1976, 176. On the pacifist movement, see Reinhold Lütgemeier-Davin, "Basismobilisierung gegen den Krieg: Die Nie-wieder-Krieg-Bewegung in der Weimarer Republik," in Pazifismus in der Weimarer Republik: Beiträge zur historischen Friedensforschung, ed. Karl Holl and Wolfrom Wette, Paderborn, Germ., 1981; also Istvan Deak, Weimar Germany's Left-Wing Intellectuals: A Political History of the "Weltbühne" and Its pathos of her mothers demystifies the bourgeois concept of the joys of maternity for the working class. As Viktoria Schmidt-Linsenhoff notes, "patience, sorrow, self-effacement, until today have never prevented war and will not do so in the future either."70

Kollwitz's prints also functioned as appeals for social amelioration and liberal reform, arousing sympathy for wounded and unemployed veterans or for the families left behind by soldiers killed in action as the most in need of social relief. Ironically, when social relief did arrive in the anniversary year, it also brought new forms of social control. Welfare agents often imitated the style of the police by invading women's homes unannounced, seeking ways to manipulate their domestic behavior, and claiming the right to surveillance. ${ }^{71}$ From the state's point of view, women's reform groups such as the Berliner Frauenbund worked to combat social ills at no cost to the state and were welcome agents of social control. They helped to discipline society, making it conform to proper moral standards and reinforcing an ideology of maternity. Regarded as Volksmutter (mothers of the people) rather than a new professional group, women welfare agents saw themselves as the custodians of morality, preservers of the family, and protectors of the communal and national good. At the same time, class boundaries and the

\section{Circle, Berkeley, 1968.}

68. Schmidt-Linsenhoff, 44

69. Käthe Kollwitz Ich sah die Welt mit liebvollen Blicken: Käthe Kollwitz in Selbstzeugnissen, ed. Hans Kollwitz, 1968, 201, quoted in Schmidt-Linsenhoff, $44-45$

70. Ibid., 44.

71. Hausin (as in n. 62), 136. 


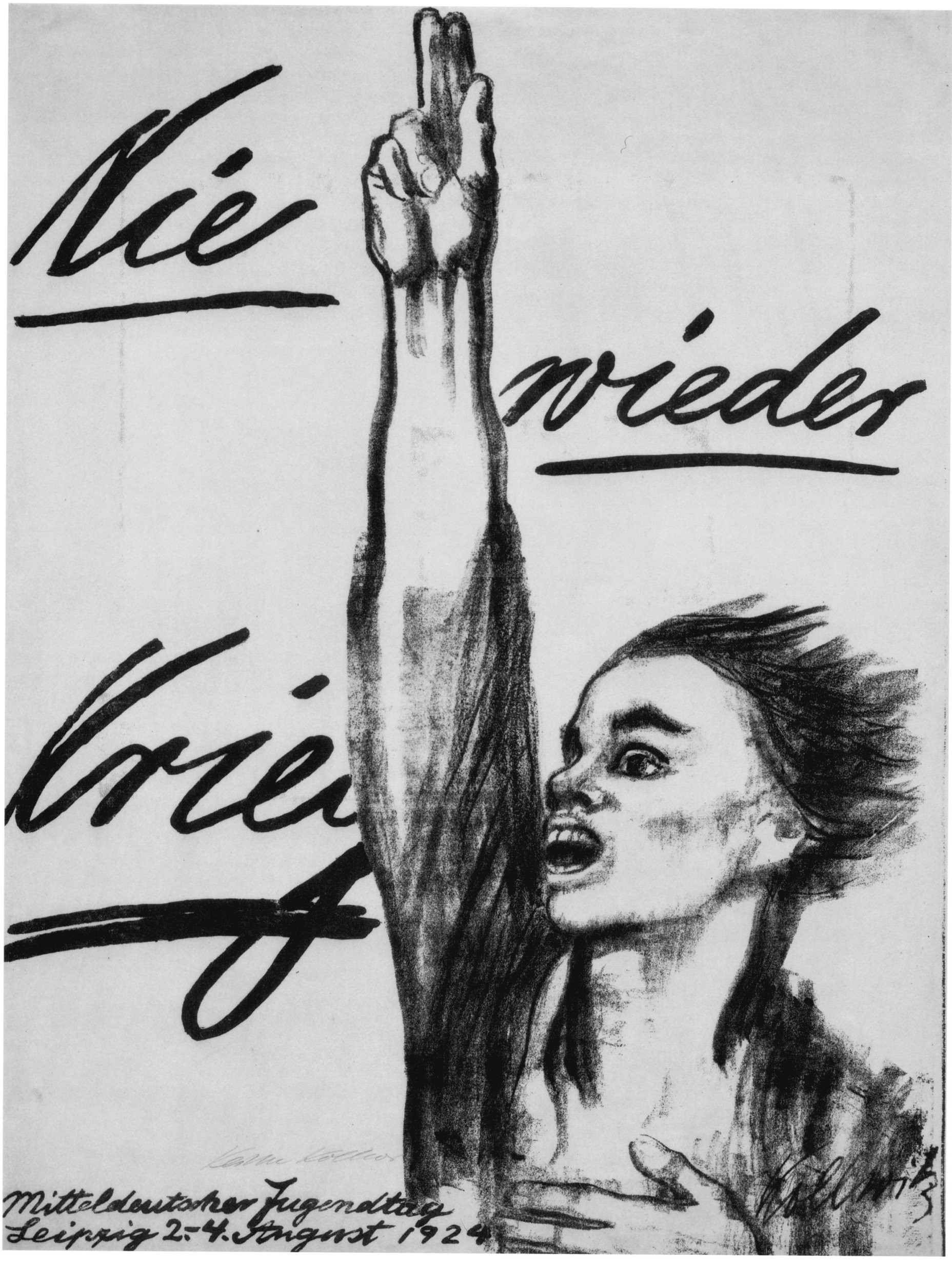

14 Käthe Kollwitz, Never Again War (Nie wieder Krieg), 1924. Washington, D.C., National Gallery of Art, Gift of Richard A. Simms (photo: (c) Board of Trustees, National Gallery of Art) 
sexual divisions of labor were carefully reinscribed in calculating economic relief to war widows based on prewar occupation or military rank of the dead husband. ${ }^{72}$

Though the political right considered itself to be the inheritor of the war experience, such left-identified artists and activists as Otto Dix, Ernst Friedrich, and Käthe Kollwitz appropriated and represented war experience for their own ends. Sometimes ambivalent, sometimes ambiguous, the complexities of their gendered antiwar representations reveal the conflicts and contradictions of Weimar liberal antimilitarism.

Kollwitz movingly portrayed the human cost of war on the home front while reinforcing a view of women as primarily maternal-and therefore bearing a greater moral responsibility for the prevention of the slaughter of the young. This was a Social Democratic pacifist trope that evaded questions of responsibility on the part of the national political leadership and naturalized the view that the woman's place was in the home, even as it countered notions of female war patriotism in Germany. Moreover, Kollwitz's pacifism was strongly qualified by her support for World War I in principle. To the degree that she supported organized pacifism after the war, her imagery took on gendered distinctions that cast feminine and masculine political roles quite differently, with a consistent emphasis on working-class feminine passivity.

Dix's more contradictory artistic imagery redefined heroism not as a gallant defense of the fatherland but as a desperate fight by the individual soldier-male against death and disfigurement. Dix's representations of war fashioned a view of male identity that produced a tension between militarist and masculinist ideology: while unsparingly depicting the vast human destruction and challenging notions of the German soldier's purity in the devastating image of rape, the dramatically virile representations of soldiers stand in contrast to the depictions of symbolic emasculation. Images of soldiers who appear feminized by their injuries and by rapacious, dominating prostitutes perpetuate, however ironically, bourgeois conceptions of manliness and the corrupted and corrupting character of prostitution.

Friedrich also deplored the barbarity of warfare, pointing not only to its destructiveness but also to the German military exploitation of foreign women as prostitutes. At the same time, he lamented the moral breakdown of German soldiers by their contaminating transactions with these same prosti- tutes. His pacifism, which depended on moral refusal, most explicitly allied itself with the bourgeois discourse of maternity that cast prostitutes as signifiers for the degeneration of the nation and mothers as the guardians of the national body. Nonreproductive versus reproductive sexuality was at the core of the perceived corruption of prostitutes, whether their depravity was marked on their bodies (as with Dix) or they were still young and attractive (as with Friedrich). Without the ambiguity of either Dix's or Kollwitz's artistic constructions, Friedrich's propagandistic and straightforward address to working-class and middle-class women most directly reinforced gender boundaries and traditional gender roles at a time when women were in competition with men over jobs and were seeking to play an increasingly active public role. In examining Weimar antiwar imagery, we can see how the visual shifts between manliness and feminization, purity and corruption, passivity and assertion both revealed and helped forge the relationship between gender identity, militarism, and the contradictions of patriarchal capitalism in postwar German society.

\section{Frequently Cited Sources}

Evans, Richard J., Comrades and Sisters: Feminısm, Socıalism and Pacıfism in Europe 1870-1945, New York, 1987.

Friedrich, Ernst, War against War! (1924), Seattle, 1987.

Schmidt-Linsenhoff, Viktoria, "Käthe Kollwitz: Weibliche Aggression und Pazifismus,” Krtische Berichte, no. 3, 1986, 36-47.

Schröck-Schmidt, Wolfgang, Die Rezension des "Schützengraben” von Otto Dix, Master's thesis, University of Heidelberg, 1989.

Theweleit, Klaus, Male Fantasies: I. Women, Floods, Bodies, History, trans. Stephen Conway, Minneapolis, 1987; Male Bodies: II. Psychoanlyzing the White Terror, trans. Erica Carter and Chris Turner, Minneapolis, 1989.

Usborne, Cornelie, The Politzs of the Body in Wermar Germany: Women's Reproductıve Rights and Duties, Houndmills, Eng., 1992.

Whalen, Robert Weldon, Butter Wounds: German Victims of the Great War, 1914-1939, Ithaca, N.Y., 1984.

Dora Apel is currently working on a book on American postwar representations of the Holocaust. Her article "The Tattoed Jew" appeared in the June 1997 issue of New Art Examiner. She teaches art history at Wayne State University [Department of Art and Art History, Wayne State University, Detroit, Mich. 48202; DoraApel@aol.com]. 
http://www.jstor.org

\title{
LINKED CITATIONS
}

\author{
- Page 1 of 2 -
}

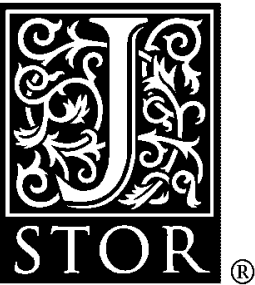

You have printed the following article:

"Heroes" and "Whores": The Politics of Gender in Weimar Antiwar Imagery
Dora Apel
The Art Bulletin, Vol. 79, No. 3. (Sep., 1997), pp. 366-384.
Stable URL:
http://links.jstor.org/sici?sici=0004-3079\%28199709\%2979\%3A3\%3C366\%3A\%22A\%22TPO\%3E2.0.CO\%3B2-S

This article references the following linked citations. If you are trying to access articles from an off-campus location, you may be required to first logon via your library web site to access JSTOR. Please visit your library's website or contact a librarian to learn about options for remote access to JSTOR.

\section{[Footnotes]}
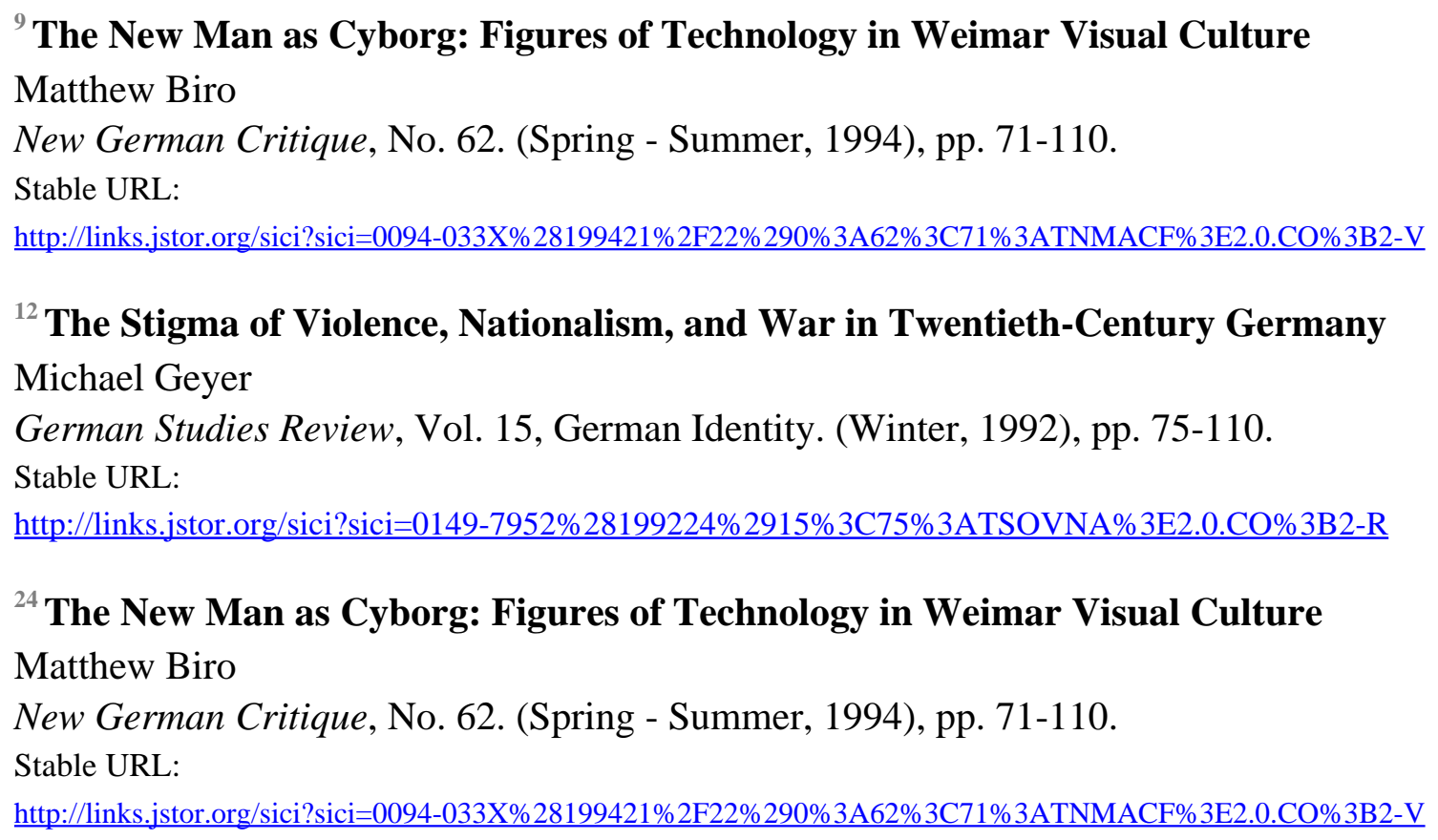
${ }^{29}$ German "Atrocities" and Franco-German Opinion, 1914: The Evidence of German Soldiers' Diaries
John Horne; Alan Kramer
The Journal of Modern History, Vol. 66, No. 1. (Mar., 1994), pp. 1-33.
Stable URL:
http://links.jstor.org/sici?sici=0022-2801\%28199403\%2966\%3A1\%3C1\%3AG\%22AFO1\%3E2.0.CO\%3B2-C

NOTE: The reference numbering from the original has been maintained in this citation list. 
http://www.jstor.org

\section{LINKED CITATIONS \\ - Page 2 of 2 -}

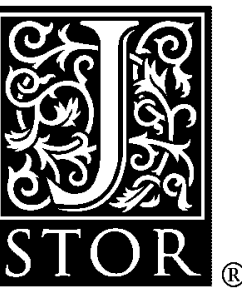

${ }^{33}$ The Most Famous Painting of the "Golden Twenties"? Otto Dix and the Trench Affair Dennis Crockett

Art Journal, Vol. 51, No. 1, Uneasy Pieces. (Spring, 1992), pp. 72-80.

Stable URL:

http://links.jstor.org/sici?sici=0004-3249\%28199221\%2951\%3A1\%3C72\%3ATMFPOT\%3E2.0.CO\%3B2-C

${ }^{37}$ Experiences of Modern Warfare and the Crisis of Representation

Bernd Hüppauf

New German Critique, No. 59, Special Issue on Ernst Junger. (Spring - Summer, 1993), pp. 41-76.

Stable URL:

http://links.jstor.org/sici?sici=0094-033X\%28199321\%2F22\%290\%3A59\%3C41\%3AEOMWAT\%3E2.0.CO\%3B2-3

NOTE: The reference numbering from the original has been maintained in this citation list. 